\title{
Permafrost in monitored unstable rock slopes in Norway - New insights from rock wall temperature monitoring, geophysical surveying and numerical modelling
}

5 Bernd Etzelmüller ${ }^{\text {a }}$, Justyna Czekirda ${ }^{a}$, Florence Magnin ${ }^{b}$, Pierre-Allain Duvillard ${ }^{b}$, Emanuelle Malet ${ }^{b}$, Ludo Ravanel ${ }^{b}$, Andreas Aspaas ${ }^{a, c}$, Lene Kristensen ${ }^{c}$, Ingrid Skrede ${ }^{c}$, Gudrun . D. Majala ${ }^{c}$, Benjamin Jacobs $^{d}$, Johannes Leinauer ${ }^{d}$, Christian Hauck ${ }^{\mathrm{f}}$, Christin Hilbich ${ }^{\mathrm{f}}$, Martina Böhme ${ }^{e}$, Reginald Hermanns ${ }^{e}$, Harald Ø. Eriksen ${ }^{g, h, *}$, Michael Krautblatter ${ }^{d}$ and Sebastian Westermann ${ }^{\text {a }}$

a Department of Geosciences, University of Oslo, Norway

${ }^{b}$ EDYTEM Lab, Université Savoie Mont Blanc, CNRS, Le Bourget-du-Lac, France

${ }^{c}$ Norwegian Water and Energy Directorate (NVE), Oslo, Norway

${ }^{d}$ Technical University Munich, Germany

${ }^{\mathrm{e}}$ Department of Geosciences, University of Fribourg, Switzerland

${ }^{f}$ Geological Survey of Norway (NGU), Trondheim, Norway

${ }^{g}$ NORCE Norwegian Research Centre AS, Troms $\phi$, Norway

${ }^{h}$ Department of Geosciences, UiT-The Arctic University of Norway, Troms $\phi$, Norway

20 * Current employer: Multiconsult Norge AS, Troms $\phi$, Norway

Key words:

Permafrost, Mountains, ERT, Monitoring, Climate change, rock slope failure 


\begin{abstract}
The warming and subsequent degradation of mountain permafrost within alpine areas is an important process influencing the stability of steep slopes and rock faces. The unstable and monitored slopes of 35 Mannen (Møre and Romsdal, southern Norway) and Gámanjunni-3 (Troms and Finnmark, northern Norway) were classified as high-risk sites by the Norwegian Geological Survey (NGU). Failure initiation has been suggested to be linked to permafrost degradation, but the detailed permafrost distribution at the sites is unknown. Rockwall (RW) temperature loggers at both sites have measured the thermal regime since 2015 , showing mean rock surface temperatures between $+2.5{ }^{\circ} \mathrm{C}$ and $-1.6{ }^{\circ} \mathrm{C}$ depending on site and aspect. Between 2016 and 2019 we conducted 2D and 3D electrical resistivity tomography (ERT) surveys on the plateau and directly within the rock wall back scarp of the unstable slopes at both sites. In combination with geophysical laboratory analysis of rock wall samples from both sites, the ERT soundings indicate wide-spread permafrost areas, especially at Gámanjunni-3. Rockwall temperatures, together with ERT measurements and modelling of the ground thermal regime strongly indicate, at least

45 locally, the presence of permafrost. Displacement rates show a seasonality, with higher velocities during spring and early summer than the rest of the year, possibly related to snow melting.
\end{abstract}

* Corresponding author:

E-mail address: bernd.etzelmuller@ geo.uio.no (Bernd Etzelmüller): 


\section{Introduction}

55 Permafrost or permanently frozen ground is a globally widespread phenomenon, and covers c. $15 \%$ of the northern hemisphere land surface (Obu et al., 2019). Permafrost is purely thermally defined, with ground temperatures below $0{ }^{\circ} \mathrm{C}$ over at least two consecutive years (van Everdingen, 1998). In southern Norway, permafrost is widespread above c. $1500 \mathrm{~m}$ a.s.1., in northern Norway above c. $800 \mathrm{~m}$ a.s.l. (e.g. Gisnås et al., 2016a). In steep rock walls, permafrost reaches hundreds of meters lower elevations in north-facing than in south-facing slopes (Magnin et al., 2019), and many rock faces in Norway are within or close to the permafrost realm. Furthermore, steep rock walls efficiently cool the ground and its surroundings because of low or lacking snow cover (Myhra et al., 2017), and they maintain strong thermal gradients in transition areas to more snow-covered regions, forming environments of more intense frost weathering (Myhra et al., 2019). While permafrost degradation in the lowlands of the Arctic is mainly

65 associated with ground ice melt (Hjort et al., 2018) and/or release of greenhouse gasses (Schuur et al., 2015;Davidson and Janssens, 2006;McGuire et al., 2010), slope instability is the major concern in mountain areas (Haeberli et al., 2010; Gruber and Haeberli, 2007). An increase in rockfall and rockslide activity has been documented following atmospheric warming (Gruber and Haeberli, 2007;Ravanel et al., 2010; Fischer et al., 2012; Frauenfelder et al., 2018; Ravanel et al., 2017). Furthermore, the increase in subzero rock temperatures reduces shear strength in steep slopes by affecting the strength of intact rock, ice and rock-ice interfaces (Krautblatter et al., 2013;Mamot et al., 2019). The specific sensitivity of metamorphic rocks similar to those investigated in this study for temperature-dependent weakening of the rock-ice interfaces has recently been demonstrated (Mamot et al., 2020) and is complemented by rock fatigue in zones with transitional rock freezing (Jia et al., 2015;Mamot et al., 2018). Recently, large

75 rockslide detachments in Karrat Fjord, West Greenland, were associated to permafrost degradation (Svennevig et al., 2020).

Large rockslides are the most destructive processes in terms of single event landslide disasters (Evans and DeGraff, 2002) and caused massive destruction and loss of life in historic time, hitting water bodies and causing displacement waves or filling valley bottoms (Hermanns et al., 2014;Hermanns et al., 2013b;Svennevig et al., 2020). The Norwegian Geological Survey has systematically mapped relevant areas over most of the Norwegian land area for such potentially destructive unstable slopes, and classified them according to their risk (Hermanns et al., 2013a;Blikra et al., 2016). Seven unstable rock slopes have been identified as high-risk objects based on their risk to cause loss of life, and are therefore permanently monitored. At least two of them are situated within the permafrost realm or close to the lower limit of 85 mountain permafrost in Norway: Gámanjunni-3 in Kåfjord/Troms, northern Norway $\left(69.5^{\circ} \mathrm{N}, 20.6^{\circ} \mathrm{E}\right)$ and Mannen in Romsdalen, southern Norway, $\left(62.5^{\circ} \mathrm{N}, 7.8^{\circ} \mathrm{E}\right)$. Both sites were deglaciated prior to the Younger Dryas (c. 12 ka BP), and showed initial displacement long after deglaciation, with calculated 
ages from c. 7-8 ka at Mannen and c. 6.6-4.3 ka at Gámanjunni-3 (overview in Hilger et al. 2021). Paleo slip rates variation during the Holocene and slip initialisation have been discussed in relation to Holocene permafrost dynamics at these sites (Böhme et al., 2019; Hilger et al., 2021), and demonstrated that present movement rates are much higher than the estimated averages rates during the Holocene. While Vick et al (2020) mostly relates these instabilities to structurally controlled rock slope deformation, we hypothesize that these higher rates might be influenced by a change in the ground thermal regime, and thus permafrost dynamics since the onset of atmospheric warming after the Little Ice Age (LIA).

95 This study evaluates the permafrost conditions and recent thermal development in these two unstable steep slopes of Norway. We present updated movement and rock wall temperature data, electrical resistivity tomography (ERT) and seismic surveys, along with numerical modelling of recent thermal behaviour of the unstable rock slopes.

\section{Setting}

The study focusses on two main sites monitored by the Norwegian Water and Energy Directorate (NVE) since 2009 (Mannen) and 2016 (Gámanjunni-3), respectively (Figure 1) (Blikra et al., 2016). Both sites are located at steep, glacially over-deepened valley sides, and were presumably ice-free during the Younger Dryas (e.g. Hughes et al., 2016), facilitating thick permafrost aggradation during the late Pleistocene and early Holocene (Myhra, 2016; Hilger et al., 2021).

\subsection{Gámanjunni-3 (Troms og Finnmark County)}

Gámanjunni-3 is located in northern Norway at the west-facing slope of the glacially eroded Manndalen valley. The instability consists of a garnet-bearing quartz-mica schist from the Caledonian orogeny

110 (Henderson and Saintot, 2011). Gámanjunni-3 is drawn as one instability of $26 \mathrm{Mm}^{3}$ (Figures 1 and 2a). Two joint surfaces delimit a wedge in form of a large block which has descended by $150 \mathrm{~m}$. The two sliding planes, oriented $217 / 51^{\circ}$ and $305 / 58^{\circ}$, are dipping steeper than the slope, cutting the regional foliation which is oriented $312 / 8 \pm 13^{\circ}$ (Böhme et al., 2019). The movement vector of the wedge dips $45^{\circ}$ with a rate of $5 \mathrm{~cm} \mathrm{a}^{-1}$, while the toe moves shallower at $4 \mathrm{~cm} \mathrm{a}^{-1}$. The rockslide is moving as one wedge

115 shaped block that is heavily fractured in the lower part with a large boulder talus at the base and a lobate boulder accumulation along the southern flank. This accumulation forms a rock glacier-like landform (Figures 1b and 2a) (Eriksen, 2018) and is discussed in more detail later. 

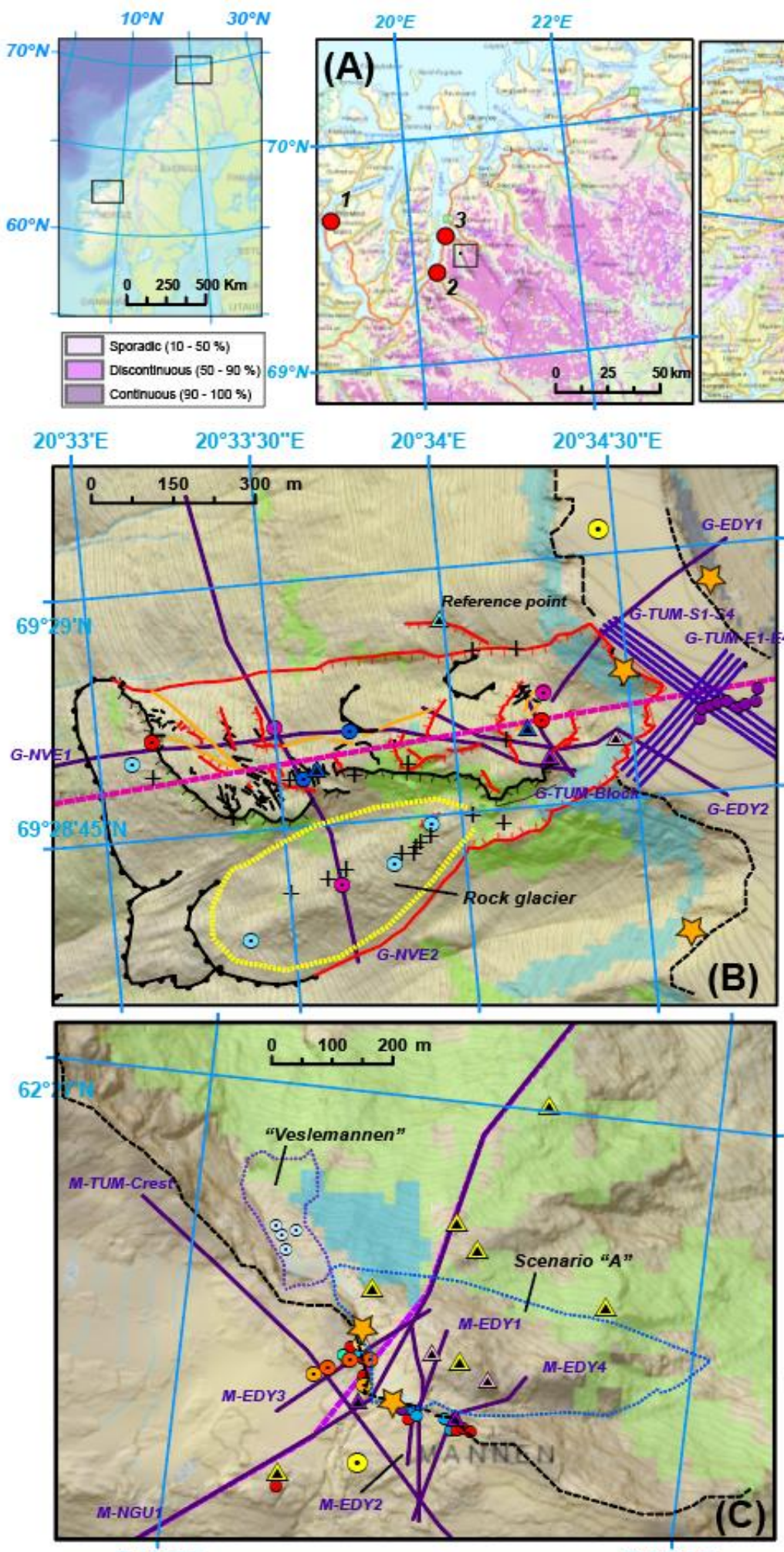

$7^{\circ} 46^{\prime} 0^{\prime \prime} \mathrm{E}$ $7^{\circ} 46^{\prime} 30^{\prime \prime} \mathrm{E}$
Measurerment devices

A GB In-SAR Radar

- Met. station

A Laser

$\triangle$ Laser target

$\Delta$ Corner reflector (Gám.)

$\Delta$ GPS (Mannen)

+ GB-INSAR (Gám.)

\section{GST classes}

$>+0.2^{\circ} \mathrm{C}$

() $-0.2-+0.2$

(e) $-0.2--1^{\circ} \mathrm{C}$

C) $<-1{ }^{\circ} \mathrm{C}$

BTS classes

- $<-3^{\circ} \mathrm{C}$

- $-2--3^{\circ} \mathrm{C}$

- $>-2{ }^{\circ} \mathrm{C}$

\section{Profiles}

ERT

- - GT model

\section{Lineaments}

$\longrightarrow$ B Back scarp

$\longrightarrow$ Scarp

- Flank

ــ Sliding pl.

Crevasse

TT Scarp

Front

PF prob.

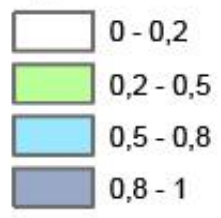


Figure 1: (A) Key map for location of the study sites. The red circles locates climate stations used for analyse rock wall surface temperature time series. The rectangles indicate the locations of the field sites. (1) Troms $\varnothing(100 \mathrm{~m}$ a.s.1.), (2) Skibotn (10 m a.s.1.), (3) Nordnes (600 m a.s.1.), (4) Åndalsnes (16 m a.s.1.), (5) Fokkstua (950 m a.s.1.), (6) Dombås (650 m a.s.1.), (7) Dovre (450 m a.s.l.). (B) Overview map over the Gámanjunni unstable area. The point symbols show measurement devices or selected points for time series extraction used in this manuscript. The yellow stippled line denotes the outline of the rock-glacier like landform. $(\mathbf{C})$ : Overview map over the Mannen unstable area. The violet stippled line denotes Veslemannen as part of the Mannen instability. The failure scenarios based are taken from Kristensen et al. (2021). The point symbols show measurement devices or selected points for time series extraction used in this manuscript. Permafrost probabilities are based on the Cryowall map of permafrost in steep slopes by Magnin et al. (2019). The dashed black line marks the crest outlining the plateaus. The orange stars indicate the location of the rock wall loggers. Base maps from (C) Statens Kartverk.

130 The mean annual air temperature (MAAT) was $-3.2^{\circ} \mathrm{C}$ during 2016-2020 on the top plateau at $1200 \mathrm{~m}$ a.s.1. The MAAT during the 1961-1990 normal period was $-4.3^{\circ} \mathrm{C}$ (Lussana et al., 2018;Saloranta, 2012), thus considerably cooler than in the recent years. During the 4 years of meteorological data, mean annual precipitation was $655 \mathrm{~mm}$. The ground is usually snow covered from November until June, with an approximate thickness of $1 \mathrm{~m}$. The site lies in the discontinuous mountain permafrost region of northern

135 Norway, and permafrost has been modelled or even measured within the slip face of the unstable rock slope (Magnin et al., 2019; Farbrot et al., 2013; Gisnås et al., 2016a;Obu et al., 2019).

\subsection{Mannen (Møre and Romsdal County)}

The Mannen rockslide is situated in the Romsdalen valley on a north-facing slope, between $900 \mathrm{~m}$ and c. $1300 \mathrm{~m}$ a.s.1. (Figure 1). The glacially over-steepened Romsdalen valley cuts through mountains comprised by gneisses that formed during the Caledonian orogeny (Saintot et al., 2012). The instability consists of an intensely folded high-grade metamorphic unit with alternating sillimanite and kyanite layers, amphibolites and pegmatites (Saintot et al., 2012). There is an exposed slip surface, building up a $20 \mathrm{~m}$ high rock wall (Figure $2 \mathrm{~b}$ ). The valley floor of Romsdalen is covered by 15 large postglacial rock slope failures, and below Mannen, 6-9 rockslide deposits are mapped, of which 3 occurred in the first

145 millennia after the deglaciation, and 3-6 slides are inferred climatically triggered during a climatic phase with increased precipitation following the Holocene Thermal Maximum (HTM) (Hilger et al., 2018). In September 2019, a smaller rockslide "Veslemannen" on the western flank of Mannen failed (Figure 2b), after episodic acceleration over several years, leading to numerous evacuations of the local population settling below Mannen (Kristensen et al., 2021). Mannen was previously proposed as a translational failure (Henderson and Saintot, 2007) and wedge failure (Dahle et al., 2010). Three scenarios define the Mannen instability (Dahle et al., 2008), where the largest has no detected movement (Figure 1c). Scenario $\mathrm{B}$ is approximately $10 \mathrm{Mm}^{3}$ with displacements of $5 \mathrm{~mm} \mathrm{a}^{-1}$ due north. Scenario A has displacements of $2.5 \mathrm{~cm} \mathrm{a}^{-1}$ dipping $60^{\circ}$, which is steeper than the topographic surface, and possibly sinking into a graben structure. 


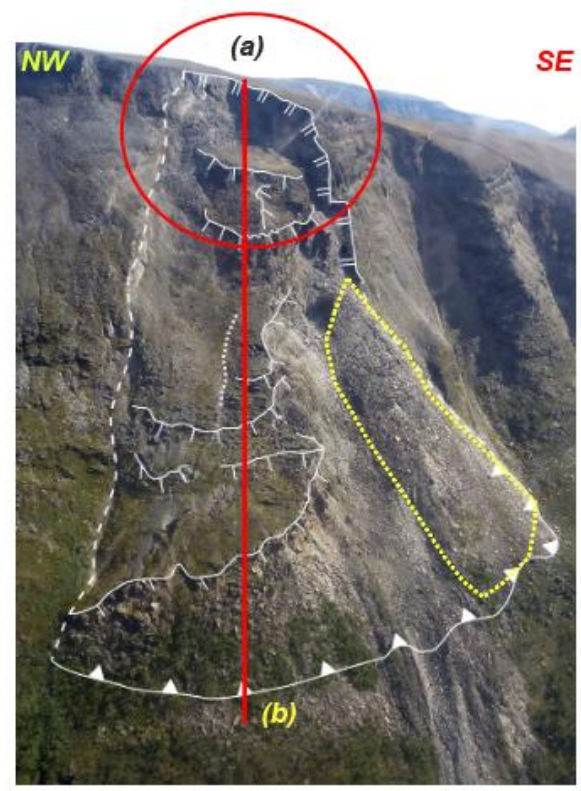

(A)
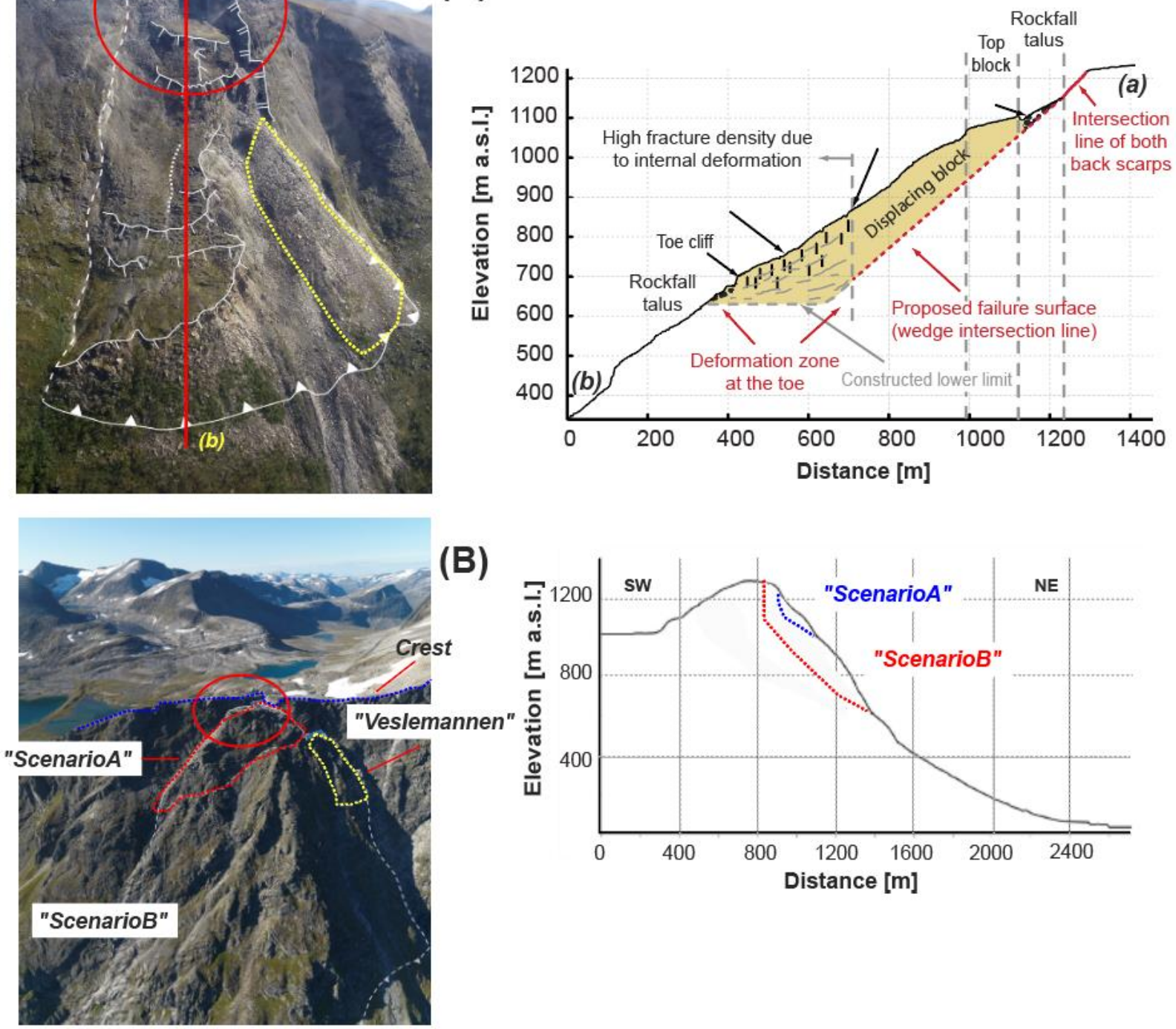

Figure 2: (A) Image (left, (C) NGU) and structure-geological model (right) of Gámanjunni (Böhme et al., 2016;Böhme et al., 2019, Eriksen et al 2017). The yellow stippled line outlines the rock glacier, the red circles show the back scarp and the moving block. The white lines indicate the different parts of the rockslide (scarps, lateral border, slide front) mapped by (Eriksen et al., 2017), similar mapping also shown in Figure 1b by NGU. The geological model forms the basis for the stratigraphy used for thermal modelling (Figure 7 and Figures A1-2). (B) Image (left, (I. Skrede/NVE) and structure-geological model of the Mannen instability (right, based on Dahle et al. (2010). The red line shows the moving part of the slope according to scenario A. The red circle shows the back scarp and the deep crevasse below, which in this picture is still snow covered. The stippled yellow line indicates the failed rockslide "Veslemannen" (Kristensen et al., 2021). 
165 During the almost 11 years of measurements, the meteorological station on top of the Mannen plateau measured an average annual precipitation of $1250 \mathrm{~mm}$ and mean air temperature of $-0.5^{\circ} \mathrm{C}$. During the last normal period 1961-1990, the mean annual air temperature was $-1.3{ }^{\circ} \mathrm{C}$ at the Mannen plateau. Atmospheric warming is therefore evident at this site during the last decades. The plateau is usually covered by a 2 to $3.5 \mathrm{~m}$ thick snow cover during the period November-June. The site lies at the lower limit of mountain permafrost, where permafrost can be expected in shaded patches or deeper crevasses (Magnin et al., 2019;Gisnås et al., 2016a;Gisnås et al., 2014;Westermann et al., 2013). Recent modelling for the small rockslide "Veslemannen" indicated at least deep seasonal frost and a thermal influence on the dynamics of the rockslide (Kristensen et al., 2021).

\section{Methods and data processing}

This study uses various data series from different measurements related to climate, rockslide movement, thermal regime and subsurface conditions. All locations of the devices and profiles used in this study are given in Figure 1.

\subsection{Movement of the rock slope}

For Gámanjunni-3, the real time monitoring was initiated in 2015, and includes Global Positioning System (GPS) antennas, crack meters, extensometer, laser to measure distances to a reflector, a meteorological station, a ground based interferometric radar system (GB InSAR), three corner reflectors and web-cameras. For Mannen, the real-time monitoring was initiated late in 2009. The continuous monitoring includes GPS antennas, distance measurements with a laser systems, extensometers, two deep borehole instrumentations, a meteorological station, web-cameras and a GB-InSAR. For this study, we use some selected GPS monitoring stations, the laser monitoring, the GB-INSAR and the corner reflectors to evaluate changes in movements of the unstable slopes. The location of the systems used in this study

190 are given in Figure 1B.

The distance laser sensor used at both sites is a Dimetix DLS-B 15, which measures with an accuracy of $1.5 \mathrm{~mm}$ and $\pm 1 \mathrm{~mm}$ in good weather conditions. The laser device registers 10 measurements per second, which are averaged for every 10 minutes. For this study daily averages are shown and used. The Trimble NetR9 GPS GNSS Reference Receiver with a Trimble Zephyr 2 antenna is measuring position

195 continuously, and processes an average position every 12 hours. The standard deviation calculated for a period between 1.8.2016 and 1.9.2020 is $\pm 0.86 \mathrm{~mm}$ and $\pm 0.69 \mathrm{~mm}$ in north and east direction, 
respectively, and $\pm 1.89 \mathrm{~mm}$ in vertical direction. However, one of the permanent points moved because of water intrusion under the foundation, hence the time series with reliable data is short.

The ground-based radar from LiSALab is a ground based InSAR system (@ Ellegi Srl) (Bardi et al., 2016; Crosta et al., 2017), placed on a concrete foundation in the respective valleys. The data were processed in the LiSALab software using an atmospheric correction region that covers a selected and assumed stable part of the slope. The reported data is derived primarily from $24 \mathrm{~h}$ averages and 3-day average measurements, which have been used to create interferograms, where the selected time-averaging period depends on the particular displacement rate at the site. The data is georeferenced to a $10 \times 10 \mathrm{~m}$ DEM. At Gámanjunni-3, time series for 8 points on the rockslide part, and 10 points on the rock glacier are extracted and further analysed (Figure 1b).

All measurements included uncertainties and white noise in the data. To reduce these effects, we calculated daily averages of movement rates, and filtered the data with a Gauss moving average filter, with variable window sizes. This procedure allowed for identifications of long-term displacement trends and possible seasonal variations of movement.

\subsection{Measured and reconstructed rock wall temperatures}

During 2015, six temperature data loggers (Geoprecision, M-Log5W-ROCK) in total were installed in the back scarps of Gámanjunni-3 (3 loggers) and Mannen (2 loggers), recording rock surface temperatures 215 (RST) with a 2-h interval, and with an accuracy of $\pm 0.05^{\circ} \mathrm{C}$ (Magnin et al., 2019) (Figure 1b). The installation procedure followed the approach described by Gruber et al. (2004). To avoid rapidly fluctuating surface temperatures sensors were placed at a depth of $\mathrm{c} .10 \mathrm{~cm}$ below the surface. We also tied to place the loggers above ledges to minimise snow influence (Magnin et al., 2019).

Automatic data loggers (Hobo and iButton) were placed on the Gámanjunni-3 rockslide and rock glacier in 2013 and 2014, measuring ground surface temperatures (GSTs), i.e. temperature below the snow cover, and temperatures in air-filled voids between crushed blocks below the surface (Eriksen, 2018). The GST loggers are distributed in three clusters over the rockslide, with data points on the moving block, the rock glacier and the toe area of the rockslide, and maintained by NVE today (Figure 1). At the Mannen site, data loggers were placed on the plateau to measure GST (Figure 1) between fall 2015 and 2018. Below the plateau, in the upper part of Veslemannen which failed catastrophically in 2019, four TinyTag (Gemini) temperature loggers were placed in fractures during two winter seasons 2014-2015 and 20152016. The aim was to record bottom temperature of snow (BTS) when the snow cover was established; however, no full years of recording exist. These data provide valuable additional thermal information of 
the rockslide and are used to compare numerical temperature modelling and geophysical investigations for permafrost mapping.

Both sites are equipped with automatic weather stations, measuring surface air temperatures (SAT), precipitation (P) and snow depth (SD). To reconstruct temperature development since the end of the LIA at the study sites, both in terms of SAT and RST, two strategies are followed: First, we used gridded climate data (daily SAT and P) available for all Norway on a ground resolution of $1 \mathrm{~km}$ since 1957. The data-set, in the following called "seNorge", is established by interpolation between meteorological stations (Lussana et al., 2018), and is daily operationally updated. Secondly, for the period before 1957 until the start of the meteorological observation period, which is during the end of the $19^{\text {th }}$ century in Norway, data from the weather stations on site and the rock wall loggers were combined with long-term series from nearby stations using simple or multiple linear regressions. For Gámanjunni-3, a good correlation with the Troms $\varnothing$ weather station was obtained (Figure 1a), where the data series started in 1867. For the Mannen site, we used both the stations in Dombås and Fokstua in central southern Norway (Figure 1a), where SAT measurements reach back to 1864 and 1923, respectively. We considered $\mathrm{R}^{2}$ scores of above 0.7 sufficient for inclusion to further analysis. These data-sets were subsequently used to derive upper boundary conditions for the numerical modelling.

\subsection{Laboratory analysis of rock properties}

In order to relate the resistivity results of the geophysical surveys to the freezing transition of specific rock types and approximate frozen rock temperatures, six representative rock samples from the study sites were tested in the freezing laboratory at the Technical University of Munich. The two samples from Gámanjunni-3 are fine-grained greenish gneiss with indicated schistosity (density $(\rho)=3.1 \mathrm{~g} / \mathrm{cm}^{3}$, porosity ca. $0.7 \%)$. Some layers contain a significant high proportion of feldspar. The one sample from Nordnesfjellet (10 km NW of Gámanjunni) is a dark grey fine gneiss to quartz-rich mica schist $(\rho=2.8$ $\mathrm{g} / \mathrm{cm}^{3}$, porosity ca. $0.6 \%$ ). Minor slightly weathered but closed clefts in different orientations and the 255 anisotropy due to foliated minerals accounts for certain deviations in the measured laboratory arrays. These correspond to variations in the field where small-scale changes of meta-sediment rock types appear. From Mannen, the three greenish to dark grey gneiss samples are medium-grained with dark and light bands of biotite, quartz and feldspar. The sample Mannen03 is coarser with a higher proportion of cmbig feldspar minerals and therefore pronounced white bands.

260 The method of the resistivity calibration follows Krautblatter et al. (2010). The samples had a cuboid shape of c. $20 * 20 * 30 \mathrm{~cm}$ and a mass of $20 \mathrm{~kg}$ to $45 \mathrm{~kg}$. All blocks were submerged in undisturbed tap water $(473 \mu \mathrm{S} / \mathrm{cm}$ conductivity) in atmospheric pressure for at least 72 hours to approach close to natural 
fluid saturation and chemical equilibrium with the pore-surrounding rock material. Each sample was equipped with three lines $(\mathrm{L}=21 \mathrm{~cm})$ of four M6 stainless steel screws in a Wenner-type array to calculate resistivity assuming an undisturbed half-space measurement geometry as the half space with the median depth of investigation controlled by electrode spacing is significantly smaller than the sample dimensions. To overcome the challenge of loss of electrical contact upon freezing, the electrodes were fitted tightly ca. $10 \mathrm{~mm}$ deep into the rock. Contact grease was applied to the electrodes in order to further improve galvanic contact. Two Greisinger GMH 3750 thermometers were put in each specimen $(5$ and $20 \mathrm{~mm}$ depth) to record both the near-rock surface temperature and the temperature at mean depth of investigation (Barker, 1989) every 30 seconds. We used an ABEM Terrameter LS, operating in monitoring mode, to obtain resistivity measurements every 15 minutes while the rock specimen where going through a freezethaw cycle between $10{ }^{\circ} \mathrm{C}$ to $-5{ }^{\circ} \mathrm{C}$ in a $1 \mathrm{~m}^{3}$ cooling box equipped with a specially designed Fryka TK1041-LK-s ventilated cooling system controlled by a temperature probe close to the sample. The cooling rate was controlled manually to not exceed a temperature gradient of more than $1 \mathrm{~K}$ between the temperatures at the rock surface and at mean depth of investigation. We used a low minimum current of $0.1 \mathrm{~mA}$ and high maximum voltage of $600 \mathrm{~V}$ to allow measurements even at high resistances supported by the high internal resistance of the ABEM Terrameter. Variance between repeated measurements (stacks) in the critical temperature interval of -2 to $+2{ }^{\circ} \mathrm{C}$ was well below $1 \%$.

\subsection{Field ERT and refraction seismic tomography}

We used non-invasive geophysical surveys along profile lines in order to map permafrost at the individual sites and provide information on possible ice-rich or ice-poor zones in the ground, We used Electrical Resistivity Tomography (ERT) at all sites, and in addition refraction seismic tomography at Gámanjunni3.

The electrical resistivity distribution of the subsurface is evaluated by injecting a current, and measuring the resulting electrical potential differences along the profile. The investigation depth depends mainly on the distances between the current electrodes employed along the profile and the profile length, with larger distance giving greater penetration depth. The obtained apparent resistivity measurements have to be inverted using suitable inversion algorithms yielding the specific electrical resistivity distribution along the 2D profiles. High electrical resistivity is normally associated either with frozen conditions/ground ice occurrences or dry blocky layers. Low electrical resistivity points to (high) liquid water contents and unfrozen conditions (Hauck, 2002). At Gámanjunni-3, ERT is combined with seismic tomography. Seismic shots along the profiles produces P-waves, which velocity distribution and resulting travel times

295 are used and applied in a subsequent data inversion. The combination of ERT and seismic refraction are used to quantify to what extent the subsurface pores are filled with ground ice, water or air (Hauck et al., 
2004; Mollaret et al., 2020), by applying the «4-phase model» (4PM) (Hauck et al., 2011). The 4PM is based on both ERT and refraction seismic tomographic surveys. The combination of both methods is able to distinguish between ice (high resistivity and medium P-wave velocities), water (low resistivity and Pwave velocities) and air (high resistivity, low P-wave velocities). For modelling details, we further refer to Hauck et al (2011) and Mewes et al. (2017).

Table 1: Electrical resistivity tomograms included into this study. Provider refers to the institution involved in the ERT survey. For G-NVE-2 co-located ERT and seismic profiles were re-analysed by Hauck and Hilbich (2018).

\begin{tabular}{|c|c|c|c|c|c|c|c|}
\hline Site/Name & $\begin{array}{c}\text { Length } \\
{[\mathrm{m}]}\end{array}$ & $\begin{array}{l}\text { Spacing } \\
{[\mathrm{m}]}\end{array}$ & $\begin{array}{l}\text { Elevation } \\
\text { [m a.s.l.] }\end{array}$ & Proto-coll & Inst. & Provider & Reference \\
\hline$G-N V E-1$ & 1150 & 10 & $1080-522$ & $\begin{array}{l}\text { GradientP } \\
\text { lus_1 }\end{array}$ & $\begin{array}{c}\text { ABEM } \\
\text { SAS4000 }\end{array}$ & NGU & (Böhme et al., 2016) \\
\hline$G-N V E-2$ & 1035 & 9 & $690-771$ & $\begin{array}{l}\text { Wenner, } \\
\text { Schlum- } \\
\text { berger, } \\
\text { seismics }\end{array}$ & $\begin{array}{l}\text { AGI } \\
\text { STING }\end{array}$ & NVE & $\begin{array}{c}\text { (GSA, 2016; Hauck and } \\
\text { Hilbich, 2018) }\end{array}$ \\
\hline$G-E D Y-1$ & 540 & 5 & $1096-1166$ & Wenner & $\begin{array}{l}\text { ABEM } \\
\text { LS }\end{array}$ & $\begin{array}{l}\text { EDYTEM } \\
\text { /UiO }\end{array}$ & This study \\
\hline$G \_E D Y-1$ & 600 & 5 & $970-1195$ & Wenner & $\begin{array}{l}\text { ABEM } \\
\text { LS }\end{array}$ & $\begin{array}{l}\text { EDYTEM } \\
/ \mathrm{UiO}\end{array}$ & This study \\
\hline $\begin{array}{l}G-T U M-S 1 \\
\text { to }-S 4\end{array}$ & 300 & 5 & $1180-1230$ & Wenner & $\begin{array}{l}\text { ABEM } \\
\text { LS }\end{array}$ & TUM & (Leinauer, 2017) \\
\hline $\begin{array}{l}G-T U M-E 1 \\
\text { to }-E 4\end{array}$ & 400 & 5 & $1220-1200$ & Wenner & $\begin{array}{l}\text { ABEM } \\
\text { LS }\end{array}$ & TUM & (Leinauer, 2017) \\
\hline$M-N G U$ & 800 & 10 & $1254-960$ & & $\begin{array}{l}\text { ABEM } \\
\text { SAS4000 }\end{array}$ & $\mathrm{NGU}$ & $\begin{array}{c}\text { (Dalsegg and Rønning, } \\
\text { 2012) }\end{array}$ \\
\hline $\begin{array}{l}\text { M-TUM- } \\
\text { scarp }\end{array}$ & 500 & 5 & $1300-1250$ & Wenner & $\begin{array}{l}\text { ABEM } \\
\text { SAS1000 }\end{array}$ & TUM & This study \\
\hline$M-R W I$ & 200 & 5 & $1270-1245$ & Wenner & $\begin{array}{l}\text { ABEM } \\
\text { LS }\end{array}$ & $\begin{array}{l}\text { EDYTEM } \\
\text { /UiO }\end{array}$ & This study \\
\hline$M-R W 2$ & 160 & 2 & $1279-1252$ & Wenner & $\begin{array}{l}\text { ABEM } \\
\text { LS }\end{array}$ & $\begin{array}{l}\text { EDYTEM } \\
\text { /UiO }\end{array}$ & This study \\
\hline$M-R W 3$ & 200 & 5 & $1279-1236$ & Wenner & $\begin{array}{l}\text { ABEM } \\
\text { LS }\end{array}$ & $\begin{array}{l}\text { EDYTEM } \\
/ \mathrm{UiO}\end{array}$ & This study \\
\hline$M-R W 4$ & 200 & 5 & $1271-1238$ & Wenner & $\begin{array}{l}\text { ABEM } \\
\text { LS }\end{array}$ & $\begin{array}{l}\text { EDYTEM } \\
/ / \mathrm{UiO}\end{array}$ & This study \\
\hline
\end{tabular}

The ERT profiles at Gámanjunni-3 and Mannen were either located on the plateaus, along the valley slopes or in the rock walls. In the rock walls we used steel screws drilled into the bedrock as electrodes, while outside the rock walls, normally steel rods were used. All measurements were carried out during late summer. At the Gámanjunni-3 site, four major datasets were obtained between 2012 and 2019, while at the Mannen site, two major datasets were collected in 2012 and 2018, respectively. Location and details of the profiles are given in Figure $1 \mathrm{~b}$ and Table 1. 
ERT data acquisition was conducted with ABEM Terrameters (SAS1000 or LS) using Wenner or Wenner-Schlumberger protocols, with the Wenner protocol providing the best signal-to-noise ratio in difficult rock wall terrains (Dahlin and Zhou, 2004). All ERT profiles were inverted using common inversion parameters within the software Res2Dinv (Loke and Barker, 1995). The colour coding followed the values obtained through the temperature-depending resistivity analysis performed in the freezing lab of TUM (cf. section 4.1), 3 to 5 inversion iterations showed sufficient convergence without overfitting. For profiles G-NVE1 and G-NVE2 at Gámanjunni-3 (Figure 1b) the 4PM was applied to investigate relative contents of water, ice and air in the ground along the survey line (Hauck and Hilbich, 2018).

\subsection{Bottom temperature of snow (BTS) survey}

BTS measurement is a simple and rapid method to evaluate possibility of permafrost conditions in field. The principle is that during the late snow season, under a snow cover of at least $80 \mathrm{~cm}$ or more, the temperature under the snow cover is decoupled from the temperature in the atmosphere, hence is governed by heat flow from the ground (Haeberli, 1973). BTS values of below $-3^{\circ} \mathrm{C}$ indicates a high probability of permafrost, while BTS $>-2^{\circ} \mathrm{C}$ indicates no permafrost. This method has been widely used and validated in mountain areas, especially since the 1980s, and has been used also in Norwegian mountains for local permafrost mapping (e.g.Isaksen et al., 2002;Brenning et al., 2005;Lewkowicz et al., 2012). At both Gámanjunni-3 and Mannen BTS surveys were carried out on the 9. and 1. March 2017, respectively 330 (Figure 1b).

\subsection{Ground temperature modelling}

The transient heat flow model CryoGrid 2D (Myhra et al., 2017) solves the two-dimensional heat diffusion equation. The thermal properties (e.g. volumetric heat capacity and thermal conductivity) depends on temperature and material type. We used the MATLAB-based finite element method MILAMIN package (Dabrowski et al., 2008). CryoGrid 2D models conductive processes, thus nonconductive heat flow processes such as convective water or air flow are neglected. The model domain is constructed as a 2D slice through a slope up to a chosen depth. An unstructured triangular mesh is generated for various subsurface thermal regions, i.e. regions with a distinct combination of water (liquid and ice), mineral, organic and air volumetric contents. The maximum allowed triangle area, which is a measure of the spatial resolution, increases typically with depth, and is assigned to every thermal region. We used bedrock thermal conductivity of $2.5 \mathrm{Wm}^{-1} \mathrm{~K}^{-1}$ for both Mannen and Gámanjunni-3 slopes. Along 
the right and left boundaries we prescribe zero-flux boundary conditions. The lower boundary (at $6000 \mathrm{~m}$ depth) is defined by a geothermal heat flux of $50 \mathrm{mWm}^{-2}$ (Slagstad et al., 2009).

The upper boundary conditions are GST time series for the surface nodes. To calculate GST at each node, we first used SAT extracted from seNorge for elevations between valley bottom and top plateau at both sites, where SAT is linearly interpolated between the surface nodes, following a lapse rate of $0.64{ }^{\circ} \mathrm{C}$ $(100 \mathrm{~m})^{-1}$ for Mannen and $0.48{ }^{\circ} \mathrm{C}(100 \mathrm{~m})^{-1}$ for Gámanjunni (Magnin et al., 2019). We subsequently 350 estimate GST using $N$-factors between 0 and 1 that link SAT and GST, hence account for the surface offset (Riseborough et al., 2008). The $N_{f}$ factor describes the winter surface offset due to snow coverage, where values close to 1 indicate no to little snow coverage, while values closer to 0 indicate a thick snow cover. $N_{t}$ factors relate surface offsets during summer, which depends on factors such as vegetation cover, direct solar radiation/shading, albedo and soil moisture. We applied relations described from snow analyses in Norway, relating $N_{f}$ factors to annual mean snow height (Gisnas et al., 2013;Gisnås et al., 2016a). In our modelling we assume $N_{f}=1$ for steep rock walls (slope $>60^{\circ}$ ) that are frequently snowfree, whereas values of $0.25-0.5$ can be used on the mountain plateaus (slope $<30^{\circ}$ ), where snow cover is thicker depending on precipitation and wind redistribution (Gisnås et al., 2016a). For the plateau, $N_{f}$ was set to 0.5 on Gámanjunni and 0.3 at Mannen due to higher snow cover at the latter site. The intermediate values of $\mathrm{Nf}$ are used at slope gradients between $30^{\circ}$ and $60^{\circ}$.

The 2D geometry of the model domains has been extracted from a 1-m-digital elevation models (www.hoydedata.no) along an approximately west-east (Gámanjunni) or south-west to north-east transect (Mannen) (Figure A1). There are normally larger temperature gradients close to the surface than in deeper layers. Hence, we constructed nodes with a distance of $0.05 \mathrm{~m}$ at the upper boundary. The subsurface thermal regions are constructed according to the geological profile for Gámanjunni (Figure 2) and our mapping of surficial sediments along the profile using orthophotos for Mannen (Figure A1), yielding hard vertical transition between the classes at the surface and depth. We then applied a stratigraphy, i.e. volumetric contents of the ground constituents, for the various surficial sediment classes at both surface and depth as presented in Westermann et al. (2013) (Figure A1).

370 For both sites, the model was initialized at deglaciation. When we assume warm-based conditions at the bottom of the ice-sheet $\left(0{ }^{\circ} \mathrm{C}\right)$, we used the methods to reconstruct deglaciation curves and climate data described by Hilger et al (2021). We ran the model yearly until $1^{\text {st }}$ September 1873 , then at weekly time steps, and in the period 1.1.2000-31.12.2018 at daily time steps. 


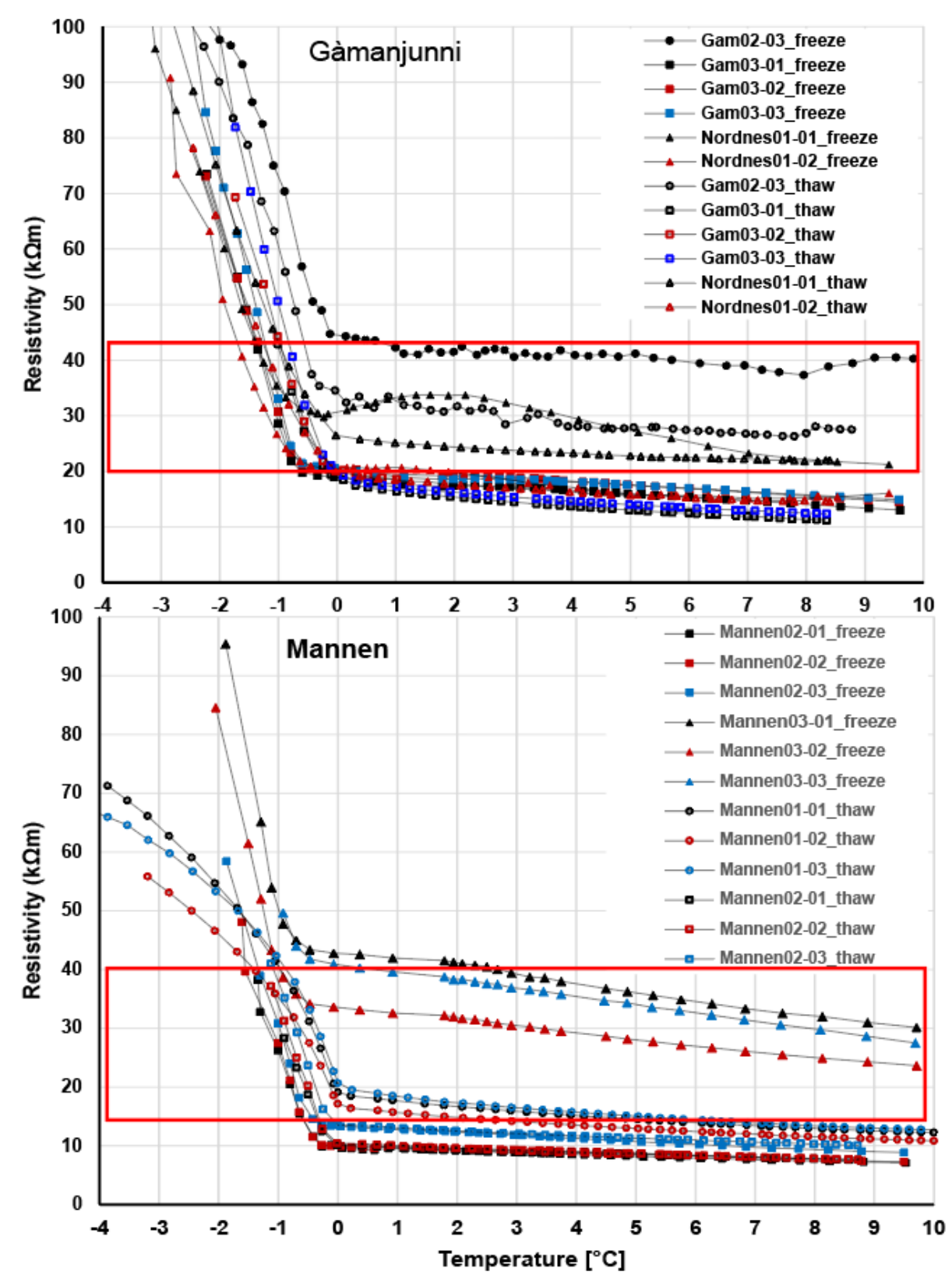

Figure 3: Temperature-resistivity plots of all successful test series for rock samples from (A) Gámanjunni and Nordnes mountain and $(\mathbf{B})$ the Mannen plateau. The red rectangles denote the transition zone between frozen and unfrozen defined based on these laboratory tests. These calibrations are used for plotting in Fig 8, 9, 10 and 12 and Figures B1-2. 

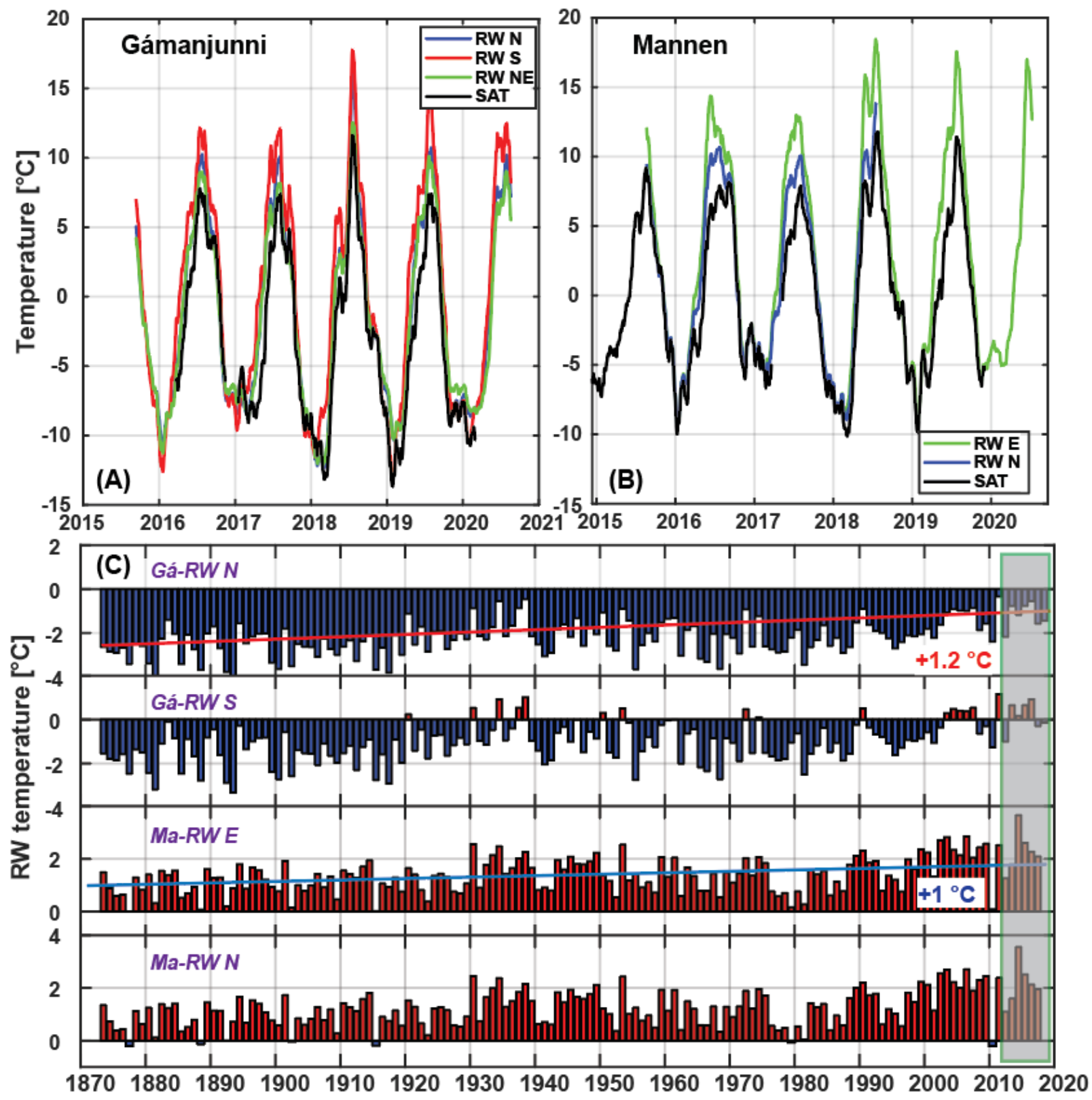

Figure 4: Measured and reconstructed rock wall (RW) surface temperatures and air temperature (SAT) on the plateaus at (A) Gámanjunni and (B) Mannen in different exposition (N=north etc). The temperature records show the differences in topographic aspect, with higher differences during spring and summer for the different aspects. (C): Reconstructed long-term annual average RW temperature for selected RW loggers at Gámmanjunni $(G a ́)$ and Mannen $(M a)$, respectively, since 1870 . The series show inter-annual variability and increasing mean temperatures of $+1^{\circ} \mathrm{C}$ or above for the 150 -year period. The rockslide and $\mathrm{RW}$ temperature monitoring period since 2011 is indicated by the shaded area, and denotes some of the highest temperatures during the 150-year-period. 


\section{Results}

\subsection{Laboratory analysis}

The laboratory analysis relates rock temperatures to resistivity. The rock samples from Gámanjunni-3 showed a similar pattern, with a sharp resistivity increase between $20 \mathrm{k} \Omega \mathrm{m}$ and $40 \mathrm{k} \Omega \mathrm{m}$ at the equilibrium freezing temperature of c. $-0.5^{\circ}$. For areas with resistivity above this range we expect negative temperatures, below we expect unfrozen conditions. The rock samples from Mannen revealed a sharp increase of resistivity below the equilibrium freezing temperature of c. $-0.3^{\circ} \mathrm{C}$, depending on bedrock type and freeze or thaw setting. The sharp increase in resistivity was between $15 \mathrm{k} \Omega \mathrm{m}$ and close to $50 \mathrm{k} \Omega \mathrm{m}$, a range we defined as the transition zone between freezing and thawing conditions.

\subsection{Gámanjunni-3}

Temperature monitoring and reconstruction - The three rock wall loggers at the unstable slope site are located all at c. $1200 \mathrm{~m}$ a.s.1., and oriented towards south (RW-S), north (RW-N) and north-west (RWNW), respectively (Figure 1). The RW-S site showed average rock surface temperatures of $+0.05{ }^{\circ} \mathrm{C}$ between 2015 and 2019, while the two other loggers had clearly sub-zero temperatures of $-1.6^{\circ} \mathrm{C}$ and $1.3{ }^{\circ} \mathrm{C}$ for RW-N and RW-NW, respectively (Figure 4a). During the same period mean SAT on the plateau was $-3.1^{\circ} \mathrm{C}$, showing that rock wall temperature was at least $+1.5^{\circ} \mathrm{C}$ higher than air temperature. For the south-oriented rock wall, close to $+3{ }^{\circ} \mathrm{C}$ warmer temperatures than SAT on the plateau were recorded. The measured RW temperatures represent a period of high temperatures in comparison to the reconstructed RW temperatures since 1870, as shown in Figure 4c. At Gámanjunni, the north-exposed logger showed sub-zero annual RW temperatures during the whole reconstruction period, while for RWS positive annual averages were mostly estimated since 2000, along with some years during the 1930s. The reconstructed long-term series clearly demonstrates the warming since the LIA, which increased with between 1 and $1.5^{\circ} \mathrm{C}$ in average for both sites.

415 The GST loggers placed over the rockslide (Figure 1b) showed mostly average annual temperatures below $0{ }^{\circ} \mathrm{C}$, with some exceptions. Average annual temperatures on the toe of the rockslide at c. $750 \mathrm{~m}$ a.s.1. revealed values between $-1^{\circ} \mathrm{C}$ and $-1.5^{\circ} \mathrm{C}$, which normally indicate high permafrost probability. On the rock glacier, annual GST values are warmer and between $-1{ }^{\circ} \mathrm{C}$ and $0^{\circ} \mathrm{C}$. In the transition between moving block and rockslide material at c. $1050 \mathrm{~m}$ a.s.l. a mean annual GST of $-2^{\circ} \mathrm{C}$ is measured (Eriksen, 2018).

420 The few BTS measurements available (Figure $1 \mathrm{~b}$ ) all showed values below $-3^{\circ} \mathrm{C}$. These observations all together place the site into the discontinuous mountain permafrost zone (Magnin et al., 2019;Farbrot et al., 2013; Gisnås et al., 2016a). 

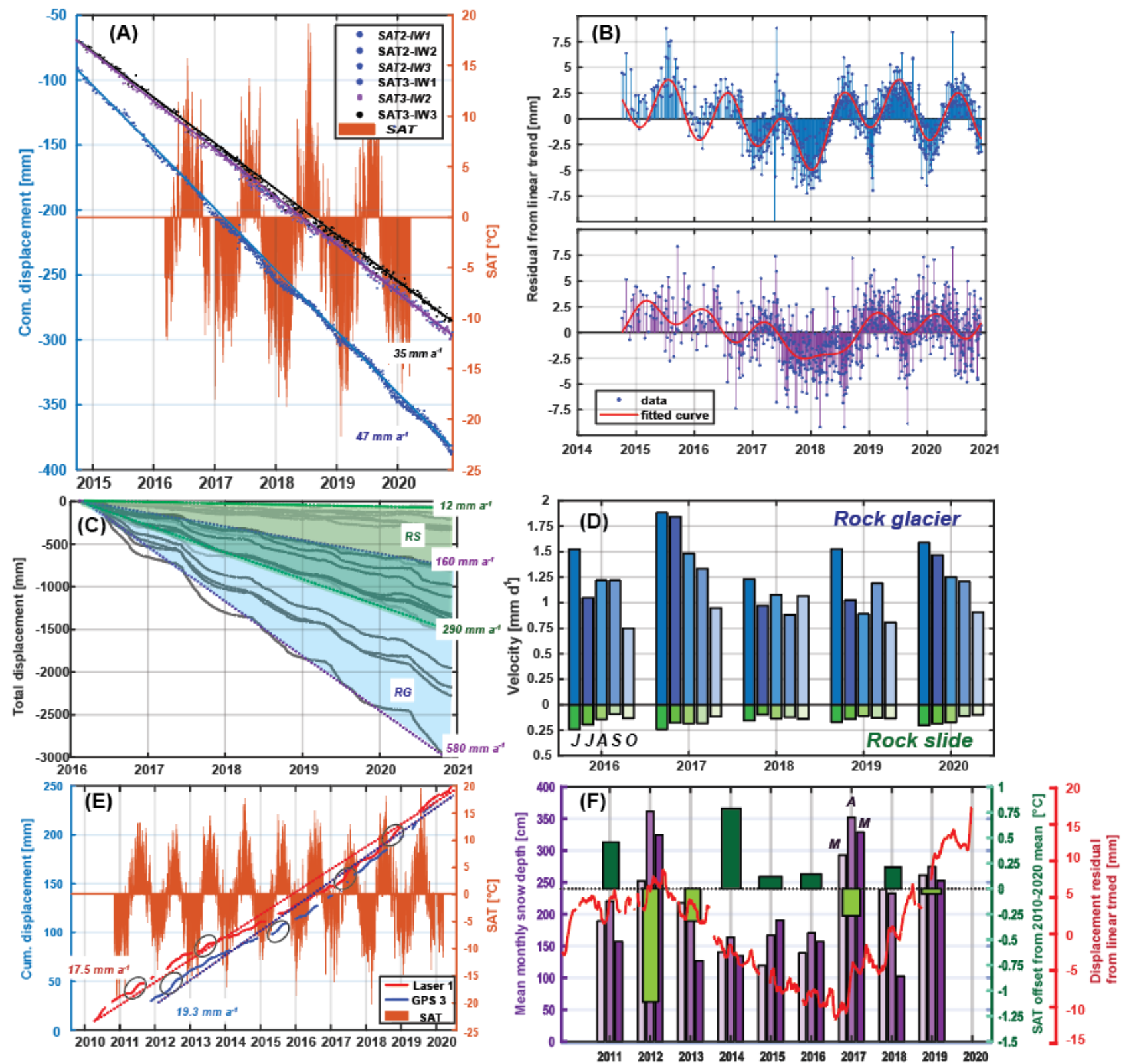

Figure 5: Displacement measurements at Gámanjunni-3 (A-D) and Mannen (E-F). (A): Accumulated displacement rates from the three corner reflectors on Gámanjunni, showing average annual displacement rates of between 35 $\mathrm{mma}^{-1}$ and $47 \mathrm{mma}^{-1}$. (B) Residuals from linear trend for SAT2 (upper) and SAT3 (lower). We fitted a third-order sinusoidal curve (red line) to the residual points. The fit indicates annual variation and a trend towards negative residuals until 2018. (C): Cumulative velocities derived at in total 18 points dispersed over the rockslide $(R S)$ and rock glacier $(R G)$ area (Figure 1) based on GB-InSAR. The green shaded envelope shows the RS points, the light blue envelope indicates the RG points. Velocities between $10 \mathrm{~mm} \mathrm{a}^{-1}$ and close to $600 \mathrm{~mm} \mathrm{a}^{-1}$ are encountered. (D) Average monthly velocity for one GB-InSAR point at the rock glacier (blue bars) and a point at the rockslide area 
https://doi.org/10.5194/esurf-2021-10

Preprint. Discussion started: 9 March 2021

(c) Author(s) 2021. CC BY 4.0 License.

(green bars). For each year the months between June and October are shown. The graph shows highest velocities early in the melting season, and highest absolute velocities in 2017. (E) Mannen: Cumulative displacement rates for GPS3 and Laser1 (Figure 1 for location), plotted with mean daily air temperatures (SAT) since 2010. There are obvious acceleration phases (some indicated by ellipses) during early spring. (F) Residuals from linear trend for 435 Mannen Laser1 (red line) against mean annual air temperatures deviation between 2010 and 2020 (orange and blue bars) and snow depth (purple bares) for the months March, April and May (M,A,M). There is a clear decrease in displacement rates between 2013 and 2017, which seems related to higher air temperatures and lower snow coverage.
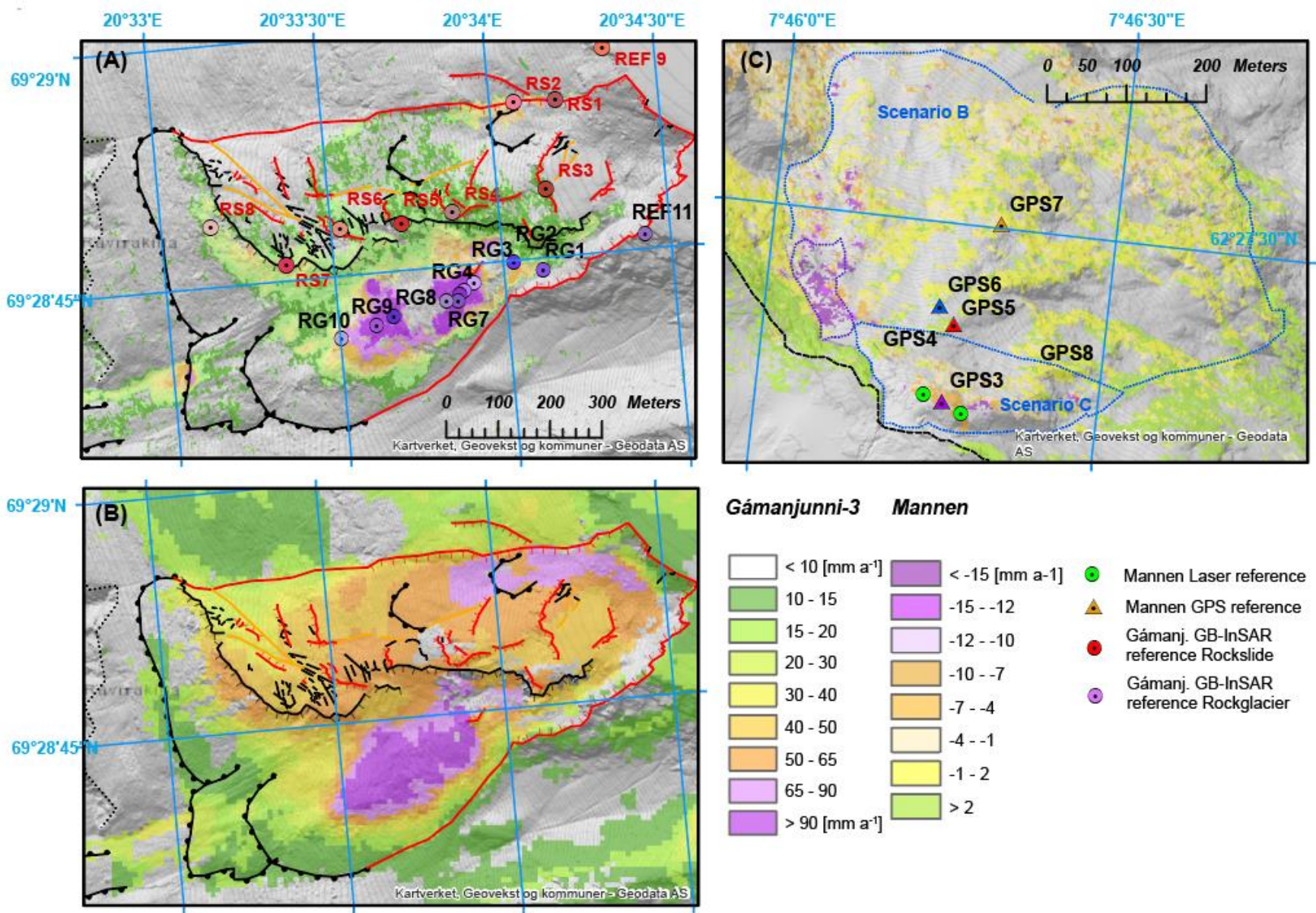

Gámanjunni-3 Mannen
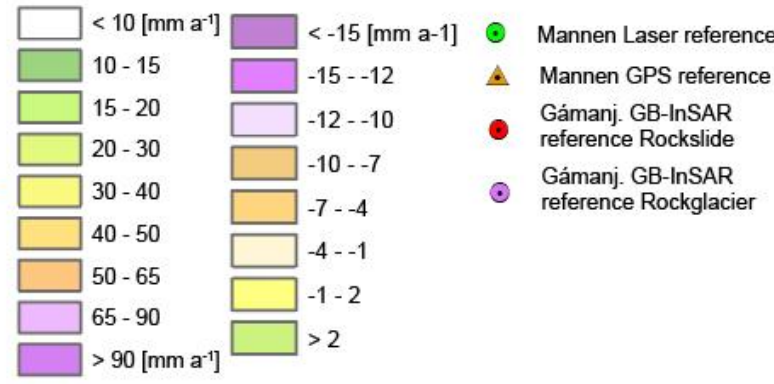

Figure 6: Spatial distribution of displacement rates for Gámanjunni (A-B) and Mannen (C). (A): The GB-INSAR map is average for the summer 2020. The circles indicate the position of time series sampling shown in Figure 5 on the rockslide (red) and the rock glacier (violet), respectively. The colour depth indicate relative differences in velocity. (B): TerraSAR-X derived averaged summer velocity collected between 2009 and 2014 (Eriksen et al., 2017). Both show clearly higher velocities in the rock glacier area. (C): GB-INSAR velocity map of the Mannen instability from summer 2020, showing relatively low displacement rates outside the upper scar area. The failed rockslide "Veslemannen" (Kristensen et al., 2021) is delineated by the dotted red line. The black line indicate the upper scarp area. The failure scenarios are based on Dahle et al (2008). Note the difference velocity scales for Gámanjunni-3 and Mannen, respectively. All base maps from ( Statens Kartverk. 
Surface displacement - For Gámanjunni-3, continuous laser and GPS measurements are available from 2018, however, the data are too short for assessing long-term variations. The site's three corner reflectors provided a continuous data series since 2015. They show a homogenous movement of between $35 \mathrm{~mm} \mathrm{a}^{-}$ ${ }^{1}$ and $47 \mathrm{~mm} \mathrm{a}^{-1}$ (Figure 5a). The residuals from the linear trend clearly shows seasonal variations with higher velocities during early spring and summer, and largest negative residuals during winter 2017/18 (Figure $5 b$ ). Time series derived from GB-InSAR in the in total 18 points revealed velocity variations between $160 \mathrm{~mm} \mathrm{a}^{-1}$ and $580 \mathrm{~mm} \mathrm{a}^{-1}$ for the 10 points on the rock glacier, and between $12 \mathrm{~mm} \mathrm{a}^{-1}$ and $290 \mathrm{~mm} \mathrm{a}^{-1}$ for the 8 points in the rockslide area (Fig. 5c-d). The data showed a clear seasonality, which however is attributed to the insecurity of the data gathered when the ground is snow covered. Monthly velocities during the snow-free months revealed in most cases (1) higher velocities early in the melting season than late, and highest summer velocities during 2017 for both the rockslide and the rock glacier part of the instability (Figure 5d). According to the RW and SAT observations this year was particular warm, and RW-S show above-zero mean annual RW temperatures (Figure 5c).

The distribution of velocity over the rockslide area shows relatively similar velocities over most of the body including the sliding block, with $40-80 \mathrm{~mm} \mathrm{a}^{-1}$, decreasing rapidly towards the slide front at $600 \mathrm{~m}$ a.s.l. (Eriksen et al., 2017) (Figure 6a-b). Highest velocities are obtained on the rock-glacier like landform 465 forming the southern part of the instability, with surface velocities of $>100 \mathrm{~mm} \mathrm{a}^{-1}$ (Figure 6b). Groundbased InSAR revealed similar velocities as the TerraSAR-X data (Figure 6a).

Numerical modelling - The temperature field revealed by the 2D temperature modelling clearly showed permafrost conditions in the slopes of Gámanjunni-3, down to 600-700 $\mathrm{m}$ a.s.l. at the end of the LIA, which includes most of the moving unstable part of the slope (Figure 7a). Since the end of the LIA, permafrost has warmed and degraded at its lower boundaries (Figure 7b), today probably only half of the moving part of Gámanjunni-3 is influenced by permafrost, while the lower parts are modelled to be permafrost-free today (Figure 7c). On the plateau, maximum snow cover is around $1 \mathrm{~m}$ thick, warming ground temperatures, while the steep rock walls are snow free and cools the sites. Snow cover and water content are sensible parameters modulating the permafrost temperature and geometry, as shown in a 475 sensitivity test (Figure A2). Permafrost thickness of more than $300 \mathrm{~m}$ are modelled, which is in agreement with similar settings where we measure deep permafrost temperatures, such as in Tarfala in northern Sweden or Juvvasshøe in southern Norway (Isaksen et al., 2001). The lower permafrost boundary is modelled to be relatively stable during the 150 year period, demonstrating that deep-seated permafrost must be expected in such settings. 

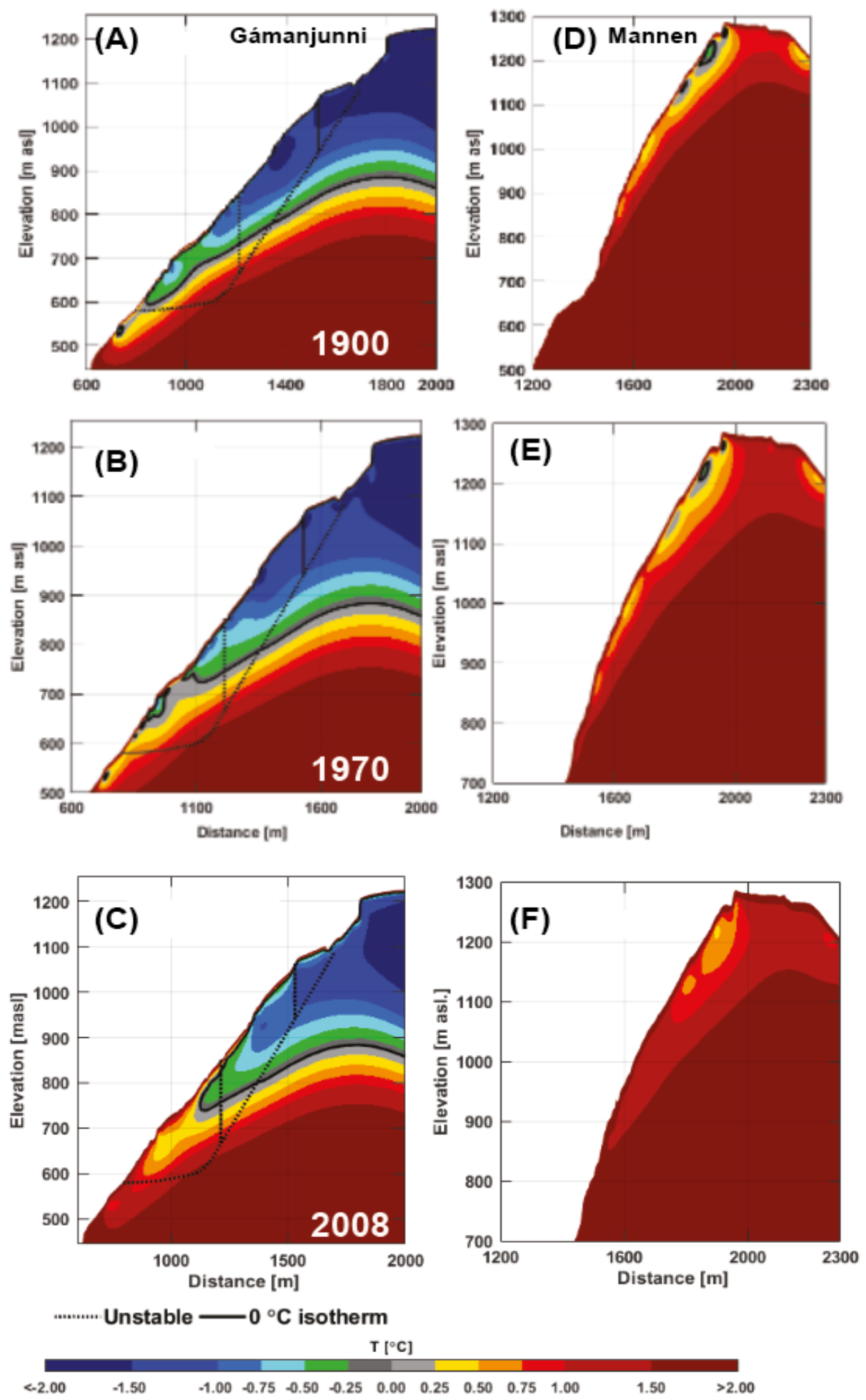

Figure 7: Modelled mean annual ground temperature for Gámanjunni-3 (A-C) and Mannen (D-F) for three different years $(1900,1970$ and 2018). The stippled line denotes the instability at Gámanjunni 3 based on Böhme et al. (2016). The black solid line in the plots show the $0^{\circ} \mathrm{C}$-isotherme. For parameterisation and sensitivity plots refer to Figures A1 and A2. 
Geophysical surveys - The two long profiles down the slope from the moving block at ca. $1050 \mathrm{~m}$ a.s.l. (G-NVE1, Figure 8a) and along the slope at c. $750 \mathrm{~m}$ a.s.l., crossing a rock-glacier like feature (G-NVE2, Figure 8 b), show consistent patterns (see also Figure B1b). General resistivity values of the unfrozen and intact bedrock at depth seems to be around $1-10 \mathrm{k} \Omega \mathrm{m}$. Surface resistivity values in the down-slope profile show a maximum between $700-900 \mathrm{~m}$ a.s.l. $(40-100 \mathrm{k} \Omega \mathrm{m})$ and further decrease to $<2 \mathrm{k} \Omega \mathrm{m}$ towards lower elevation (Figure 8a). This altitudinal transition roughly coincides with the numerical temperature modelling ( $c f$. Figure 7c). The profile G-NVE2 is oriented from south to north (Figure $8 \mathrm{~b}$ ). The overall resistivity values within the rock glacier are lower $(10-20 \mathrm{k} \Omega \mathrm{m})$, and the more resistive surface layer is shallower compared to the rockslide part in the centre of the profile. Both profiles show resistive surface layers of up to $50 \mathrm{~m}$ in thickness. In combination with the GST values by Eriksen (2018) and NVE this resistive near-surface layer could indicate permafrost patches.

The 3D profiles (G-TUM-S1-S4 and G-TUM-E1-E4) on the plateau clearly demonstrate the cooling influence of the $\mathrm{NW}$-oriented rock wall, which becomes less pronounced with distance from the wall (Figure 9a-c, Figure B1b). In addition, low-resistivity areas $(<20 \mathrm{k} \Omega \mathrm{m})$ are visible, probably indicating thawed conditions associated to water-filled crevasses and cracks in prolongation of the exposed sliding surfaces (Figure $9 \mathrm{a}-\mathrm{b}$ ). These discontinuities oriented parallel and perpendicular to the profiles may account for differences in overlapping tomograms. The east-oriented profiles (TUM-E) are clearly influenced by the SW-oriented rock wall, with generally lower resistivity compared to TUM-S close to the NW-oriented rock wall. ( $>60 \mathrm{k} \Omega \mathrm{m}$ ) areas, which are highly influenced by the rockwalls (Figure 10, 535 Figure B1c).

The G-EDY1 ERT-profile crosses the south-exposed rockwall, and shows lower resistivity values close to the rock wall surface $(<20 \mathrm{k} \Omega \mathrm{m})$, decreasing towards the north-side of Gámanjunni-3 (Figure 10a). The transition between the rockwall and the moving block below is covered by blocky scree material and show high resistivity $(>100 \mathrm{k} \Omega \mathrm{m})$ (Figure 10a). The G-EDY2 ERT-profile transverses the NW-oriented rock wall, with higher resistivity at the surface, clearly indicating the temperature differences between the two rock faces (Figure 10b). Also here, high resistivity patches are found under the moving block and the cooled rock wall, while lower resistivity are found under the snow-covered plateau $(<15 \mathrm{k} \Omega \mathrm{m})$ (Figure $10 \mathrm{~b}$ ). It is obvious that the moving block is an area of high resistivity, with possible permafrost influence or a set of air-filled fractures developed during the instability. These higher values are also visible at a cross profile over the structure (G-TUM-Block) (Figure 10c). 

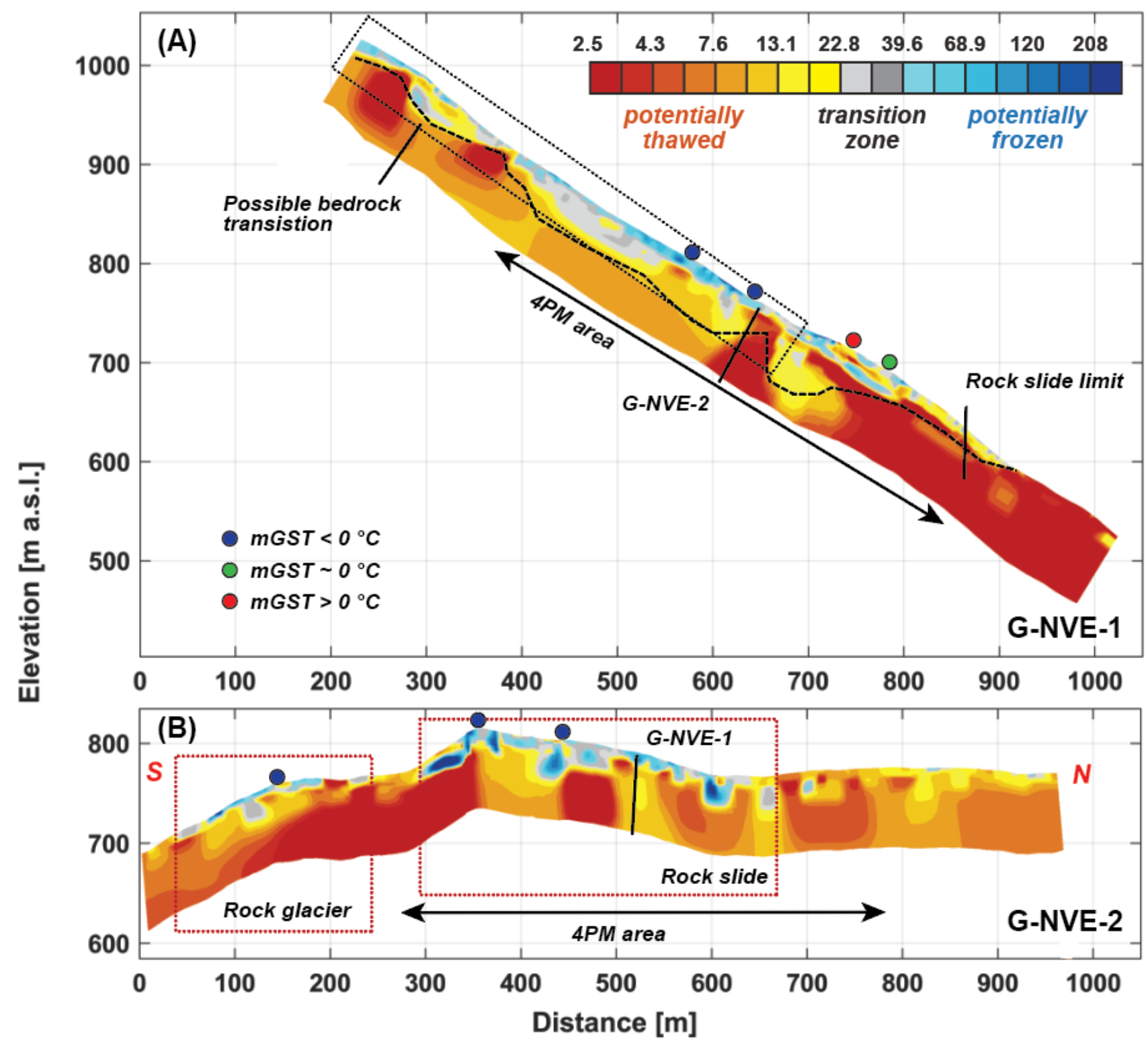

Figure 8: The long ERT profiles for Gámanjunni-3. The colour scale follows the laboratory analysis shown in Figure 3. (A) G-NVE1, showing high resistivity layers down to c. $700 \mathrm{~m}$ a.s.l. (box). The dashed line indicates the possible transition to solid bedrock. (B): G-NVE2, the cross profile over the rock glacier and the lower rockslide area, indicated by the red boxes. The circles in both profiles indicate location and mean annual GST in the vicinity of the profiles, based on Eriksen (2018) and subsequent measurements (NVE, unpublished data). They show subzero temperatures in areas with high resistivity surface layers, and higher values below $700 \mathrm{~m}$ a.s.l. The part of the profile used for the 4-phase.model (4PM) is indicated in both profiles (Figure 11). 


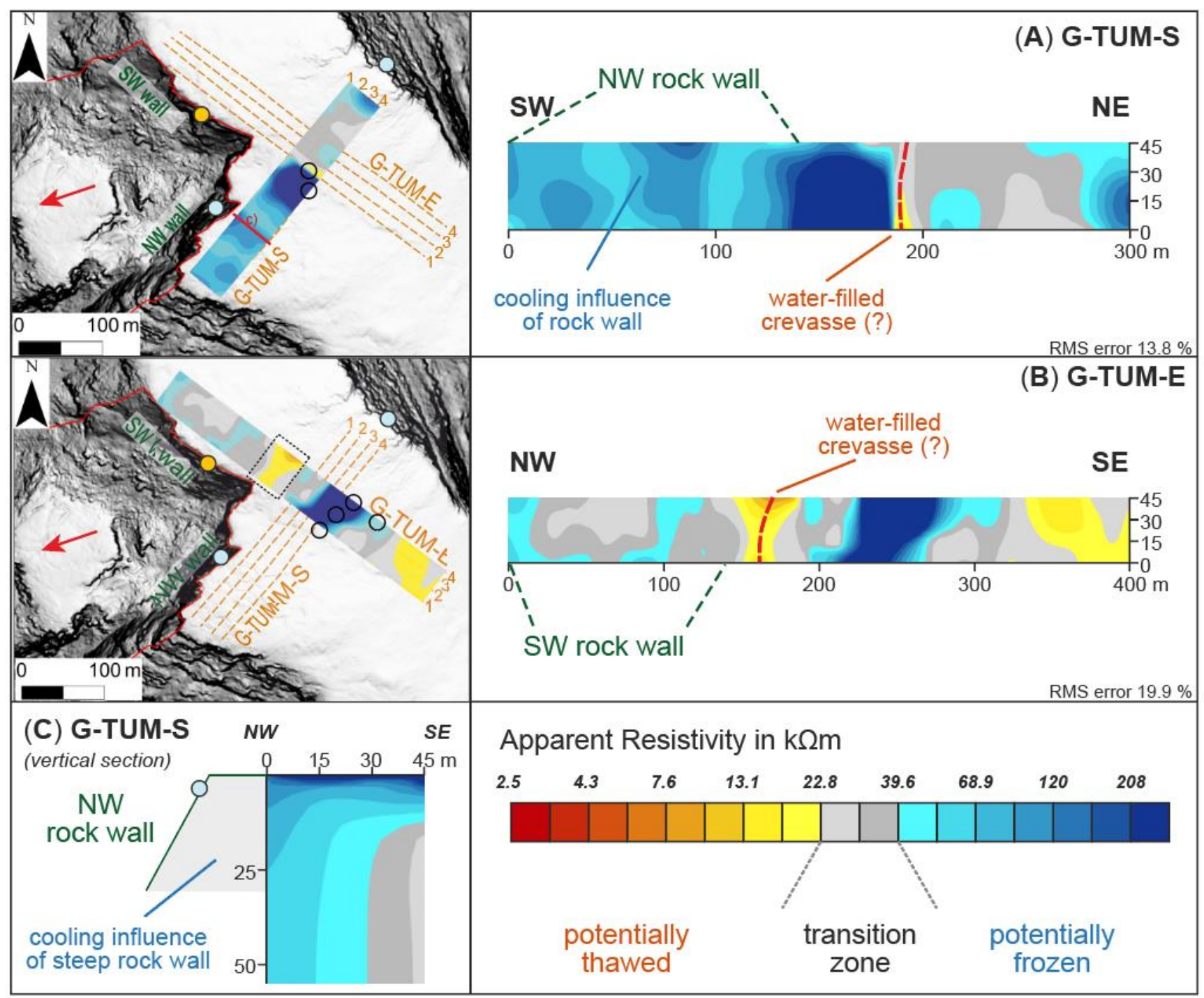

Figure 9: Quasi 3-D surveys on the Gámanjunni-3 plateau above the instability. The illustration shows a section interpolated for $10 \mathrm{~m}$ depth for $(\mathbf{A})$ the south-oriented profiles $(G-T U M-S)$, and $(\mathbf{B})$ the east-oriented profiles $(G-$ $T U M-E)$. There is a high variability in resistivity, and unfrozen parts are indicated interpreted as water-filled crevasses. See main text for more details. $(\mathbf{C})$ : Interpolated vertical profile close to the NW-oriented rock wall, showing the thermal influence of the steep and probably snow free area. The location of the cut is indicated as red line in (A). The blcak circles denotes BTS measurements, showing all at $<-3{ }^{\circ} \mathrm{C}$ and probable permafrost. These measurements are all situated in high resistivity areas. The filled circles show average annual temperatures for the rock wall loggers (Figure 4a), with light blue $=<-1{ }^{\circ} \mathrm{C}$ and orange $>0{ }^{\circ} \mathrm{C}$. Base maps $\odot$ Statens Kartverk. 


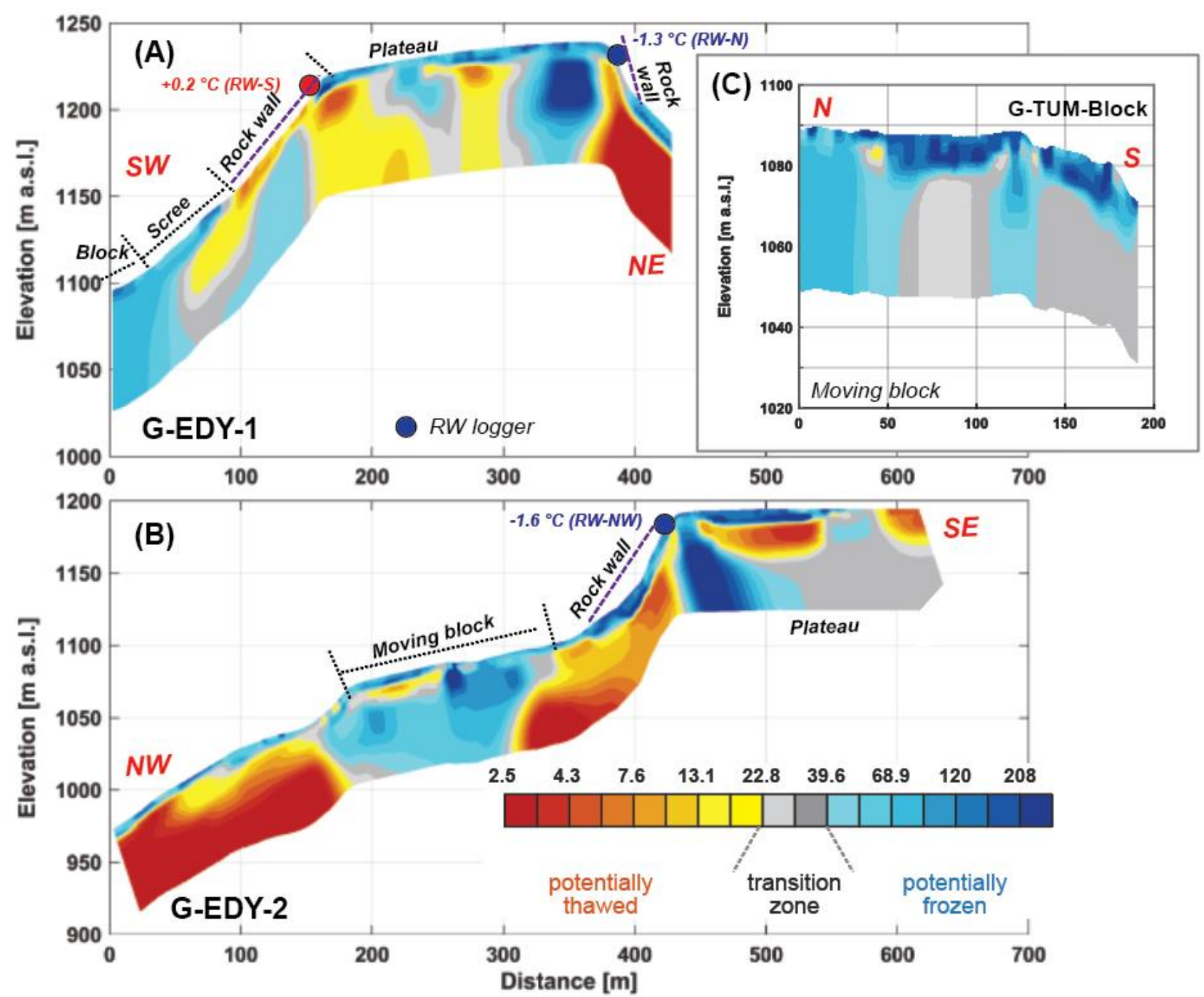

Figure 10: ERT surveys over the back scarp at Gámanjunni-3, (A) G-EDY1 which is oriented over the exposed part of the slip surface. While the rock wall show low resistivity, there is a clear transition towards the scree and the moving block with considerable higher resistivity. (B) G-EDY2 which is placed over the north-western exposed part of the rock wall. There are significant higher resistivity in both rock wall and plateau, illustrating that this side is more influenced by the cooler rock wall. For both profiles, the location of the rock wall loggers are indicated as circles. (C): G-TUM-block oriented NW to SE over the moving block below the slip face. The resistivity is relatively high in relation to the plateau and below the block. 
575 The combination of ERT and refraction seismic tomography within the 4PM revealed clear patterns in relation to possible permafrost and ice saturation (Figure 11, (Hauck and Hilbich, 2018)). At the G-NVE2 ERT profile, the considerable ice content values of up to 50-80\% saturation suggests permafrost conditions. We also see heterogeneities in vertical and horizontal directions along the profile line (Figure 11b). The overall water contents are mostly low. The exceptions is a possible fracture zone at depth (horizontal distance 180-230 m) (Figure 11a), showing greater ERT heterogeneities and low seismic velocities (Figure $\mathrm{Clb}$ ). Such a pattern is normally associated with high subsurface air contents. This kind of low P-wave velocities (=high air contents) at greater depths is not common, and more prominently discussed in the reports concerning the original seismic and ERT results of the area (GeoExpert, 2016). Unfrozen surface layers with no ice along G-NVE2 for the uppermost 5-10 $\mathrm{m}$ are further suggested by 585 the analysis, while the northern part of the profile show a higher ice saturation within the upper $30 \mathrm{~m}$ (Figure 11b). Finally, overall dry conditions are suggested by modelled high air contents near the surface. The overall ice-content is probably low even if the model indicate high ice-saturation. This is related to the low-porosity bedrock (porosity c. $0.7 \%$, (Leinauer, 2017)), which is in coincidence with resistivity values of only $\sim 10 \mathrm{k} \Omega \mathrm{m}$, which are more atypical for high ice contents (Figure $\mathrm{C} 1 \mathrm{~b}$ )). We prescribed a laterally homogeneous porosity model in the $4 \mathrm{PM}$, which probably led to an overestimation of ice saturations due to low-porosity bedrock in the right-hand side of the profile.

Also along the slope of the instability (G-NVE1) the results suggest permafrost conditions. This is especially evident for the upper part of the profile (Figure 11a). We also could identify an unfrozen surface layer, even if this feature is less visible due to geometry reasons, and a fracture zone characterised by high air contents (150-280 m horizontal distance, Figure 11a). We also note that the values for the geophysical profiles at the crossing points of the two profiles are quite correspondent. There, the transition between predominantly high ice saturations and high water saturations (which could be interpreted as a transition zone between frozen and unfrozen conditions) is in both cases at around 40-50 m depth. However, also here we prescribed by a gradient model for porosity which was lateral homogenous, so such transitions in the data could also be due to change in material properties. However, we are relatively confident of the reliability of our analysis, as the 4PM resulted in similar values at the cross-over area of both profiles.

The results indicate permafrost conditions in both profiles, with an at least 30-50 m thickness. In addition, strong heterogeneities especially regarding de-compaction and fracture zones have been found, indicating significant air contents at larger depths, which is seldom found in thermally stable mountain permafrost bodies 

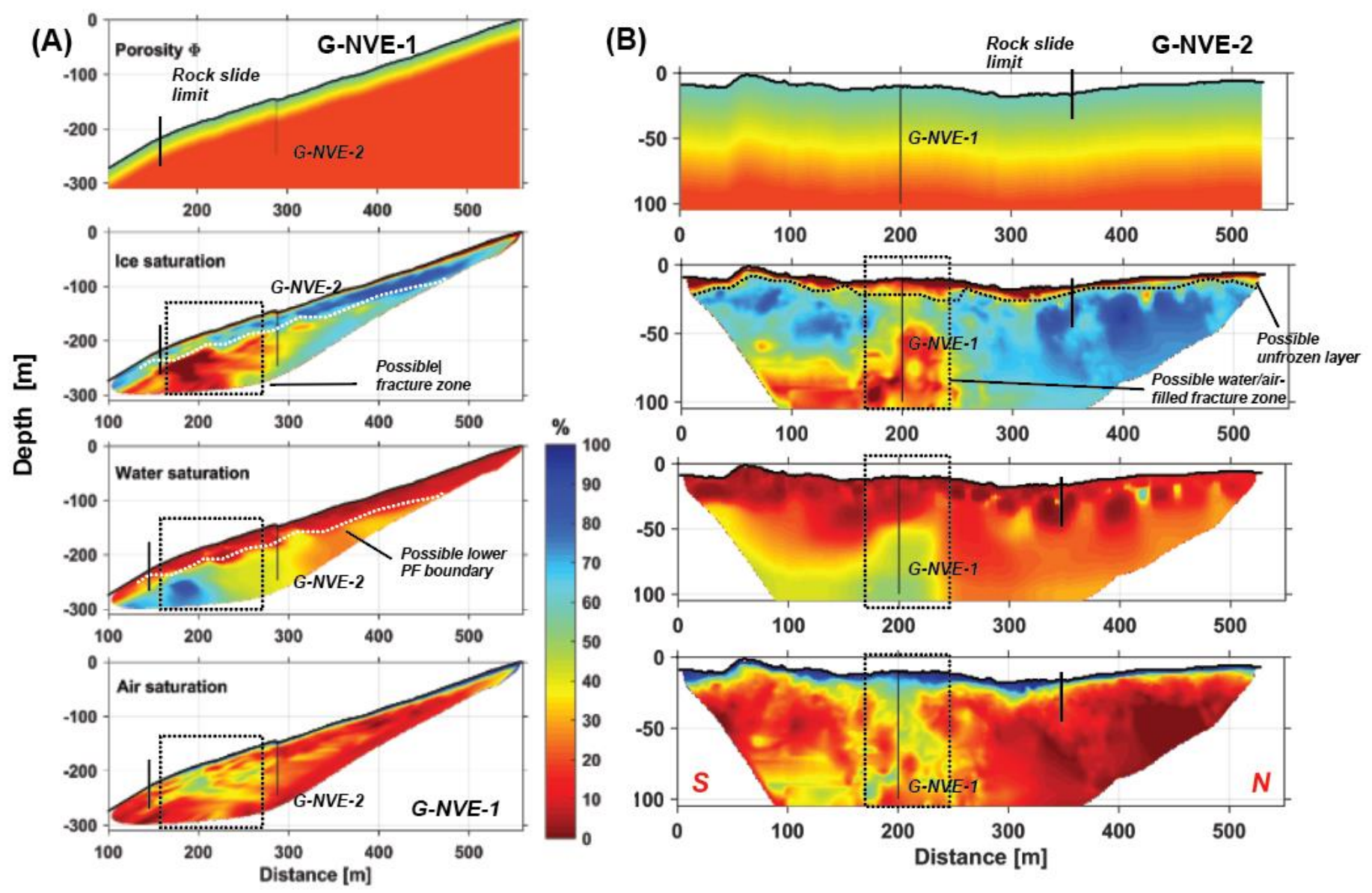

Figure 11: Saturation of pore space determined using the 4-phase model (4PM) based on Hauck and Hilbich (Hauck and Hilbich, 2018) for (A) the long profile along the slope G-NVE1 and (B) the transversal profile GNVE2. The total saturation values for ice, water and air are given in relation to the porosity prescribed in the uppermost plots for the respective profiles. The model clearly indicates high ice saturation in parts of both profiles, thus suggesting the presence of permafrost. The potential fracture zone discussed in the main text are indicated by the black boxes. The possible unfrozen layer are indicated in $(\mathbf{B})$, while the possible lower permafrost boundary is indicated in (A) for G-NVE1. Note that the tomograms are subsets of Gam-NVE-1 and 2 and thus shorter than the profiles shown in Figure 8.

\subsection{Mannen}

Temperature monitoring and reconstruction - The two rock wall loggers are oriented towards north (RW$\mathrm{N}$ ) and east (RW-E), respectively (Figure 1c). Both loggers showed positive annual average temperatures 620 during 2015 and 2019 , with $+1.2{ }^{\circ} \mathrm{C}$ and $+2.6{ }^{\circ} \mathrm{C}$, respectively (Figure $4 \mathrm{~b}$ ). During the same period, the 
mean air temperature on the plateau was $0{ }^{\circ} \mathrm{C}$, showing that rock wall temperature was at least $+1{ }^{\circ} \mathrm{C}$ higher than air temperature. The reconstructed RW temperature series since 1970 revealed above-zero temperatures in the rock wall, with an increasing trend (Figure 4c). The north-exposed rock wall certainly featured sub-zero temperatures in some cold years, at least one being in 2011.

GST loggers distributed along the rock scarp (Figure 1b) showed mean GST between +0.9 and $+1.6{ }^{\circ} \mathrm{C}$, showing the warming influence of the thick snow cover. The TinyTag loggers in Veslemannen (Figure 1c) recorded BTS temperatures in fractures between $-1.3{ }^{\circ} \mathrm{C}$ and $-1.8^{\circ} \mathrm{C}$ in late April - early May 2015. In late April 2016 the BTS recorded was between $0{ }^{\circ} \mathrm{C}$ and $-2.3^{\circ} \mathrm{C}$. The mean temperatures recorded by these loggers are not representative, as they all lack complete annual data, but have to be around $0{ }^{\circ} \mathrm{C}$ in annual average. These data are described in more detail in Kristensen et al. (2021). Most of the BTS measurements were conducted close to the edge of the back scarp. While BTS-values were mostly below $-2{ }^{\circ} \mathrm{C}$ behind the north-exposed scarp, BTS values above $-2{ }^{\circ} \mathrm{C}$ dominate behind the east-oriented edge (Figure 1c). The data confirm that permafrost patches occur likely along the plateau edge (Magnin et al., 2019).

635 Surface displacement - For the GPS and laser station velocities between 14 and $20 \mathrm{~mm} \mathrm{a}^{-1}$ are recorded (Figure 5e). The data indicate higher velocities during the start and last years of measurements, with a slow-down between c. 2013 and 2016, and a subsequent acceleration (Figure 5f). In the first period between 2010 and 2013 in southern Norway had cold winters (MAAT of $-1{ }^{\circ} \mathrm{C}$ on Mannen at $1200 \mathrm{~m}$ a.s.l.) (Figure 5g). After 2013 temperature increased by $1{ }^{\circ} \mathrm{C}$ on average (MAAT $=-0.1{ }^{\circ} \mathrm{C}$ between 2013 640 and 2020). The slow-down of displacement rates between 2013 and 2016 seems to be associated with a lower snow cover during the winters of these years (Figure 5f). In terms of seasonal variations the cumulative movement plots indicate a step-wise pattern, with higher and lower velocities during spring/summer and fall/winter, respectively (Figure 5f). This is different to what was observed at Veslemannen, where velocity accelerations started during the snow melt period, but was much higher and more variable in the fall period, and after heavy precipitation events (Kristensen et al., 2021).

The distribution of velocities over the moving slope body was derived from GB-InSAR, and shows highest velocities in the upper part just below the back scarp and the plateau, with $>20 \mathrm{~mm} \mathrm{a}^{-1}$ (Figure 6c). This high-velocity area corresponds with scenario A for Mannen (Fig. 1c).

Simulated ground temperatures - The temperature field revealed by the 2D temperature modelling 650 indicates possible permafrost conditions in the steep part of the slope during the onset of modelling at the end of the LIA, with permafrost thicknesses of between 50 and $100 \mathrm{~m}$ depending on spin-up (Figure 7d) and snow cover parameters (Figure A2b). During the 150 years of the model run, steady warming reduced and degraded the modelled permafrost. However, isolated patches might still be possible in the steepest part with less snow, depending on model parametrisation in terms of snow coverage and water content in 
the model domain (Figure A2b). Today, deep seasonal frost is modelled in the steep parts which is coincident with the rock wall measurements in the back scarp (Figure7f, Figure 4b). The plateau is heavily snow covered, and frost penetration is only possible laterally from the snow-free steep slopes.

Geophysical surveys - The ERT profiles at Mannen show generally higher resistivity than at Gámanjunni3 , probably related to different background resistivity of the bedrock and less surficial sediment cover.

660 The $1 \mathrm{~km}$ profile (M-NGU1, (Dalsegg and Rønning, 2012)) covers both the plateau and the steep unstable slope, and showed comparatively low resistivity $(10-40 \mathrm{k} \Omega \mathrm{m})$ at depth (probably indicating the resistivity of the unfrozen intact bedrock), and higher resistivity at and below the scarp close to the surface down to c. $1150 \mathrm{~m}$ a.s.l. (50 - >100 k $\Omega \mathrm{m}$ ) (Figure 12a). These high resistivity areas reveal crushed airfilled and well-drained bedrock and may contain permafrost patches (Dalsegg and Rønning, 2012). The ERT profile along the crest (M-TUMI-scarp) show decreasing resistivity from NW to SE (Figure 12b). High resistivity (>100 k $\Omega \mathrm{m}$, possibly indicating frozen conditions at depth) are observed close to the rock wall, while low resistivity $(<30 \mathrm{k} \Omega \mathrm{m})$ dominates in the southeast, where the profile departs from the crest, and in the upper c. $20 \mathrm{~m}$ of the profile. The highest values $(>300 \mathrm{k} \Omega \mathrm{m})$ are observed around a deep crack delimiting one of the moving blocks at Mannen, which defines a fractured zone with possible high porosity and unsaturated conditions (Figure 12b).

The rock wall profiles (M-EDY1-4) show mainly resistivity $<40 \mathrm{k} \Omega \mathrm{m}$, also at depth, on the plateau, and higher resistivity $(>50 \mathrm{k} \Omega \mathrm{m})$ over the back wall and over the crevasses between the back scarp and the moving block (Figure 12c-f). Again, the highest values are measured below the back scarp over large crevasses, which contain much air and are possibly partly snow and possibly ice filled. An exception is the M-EDY-2 profile (Figure 12d), where high resistivity is also obtained on the plateau. This profile has 2-m spacing, giving a higher resolution close to the surface, and represents probably the coarse and highporosity block cover on the plateau. 

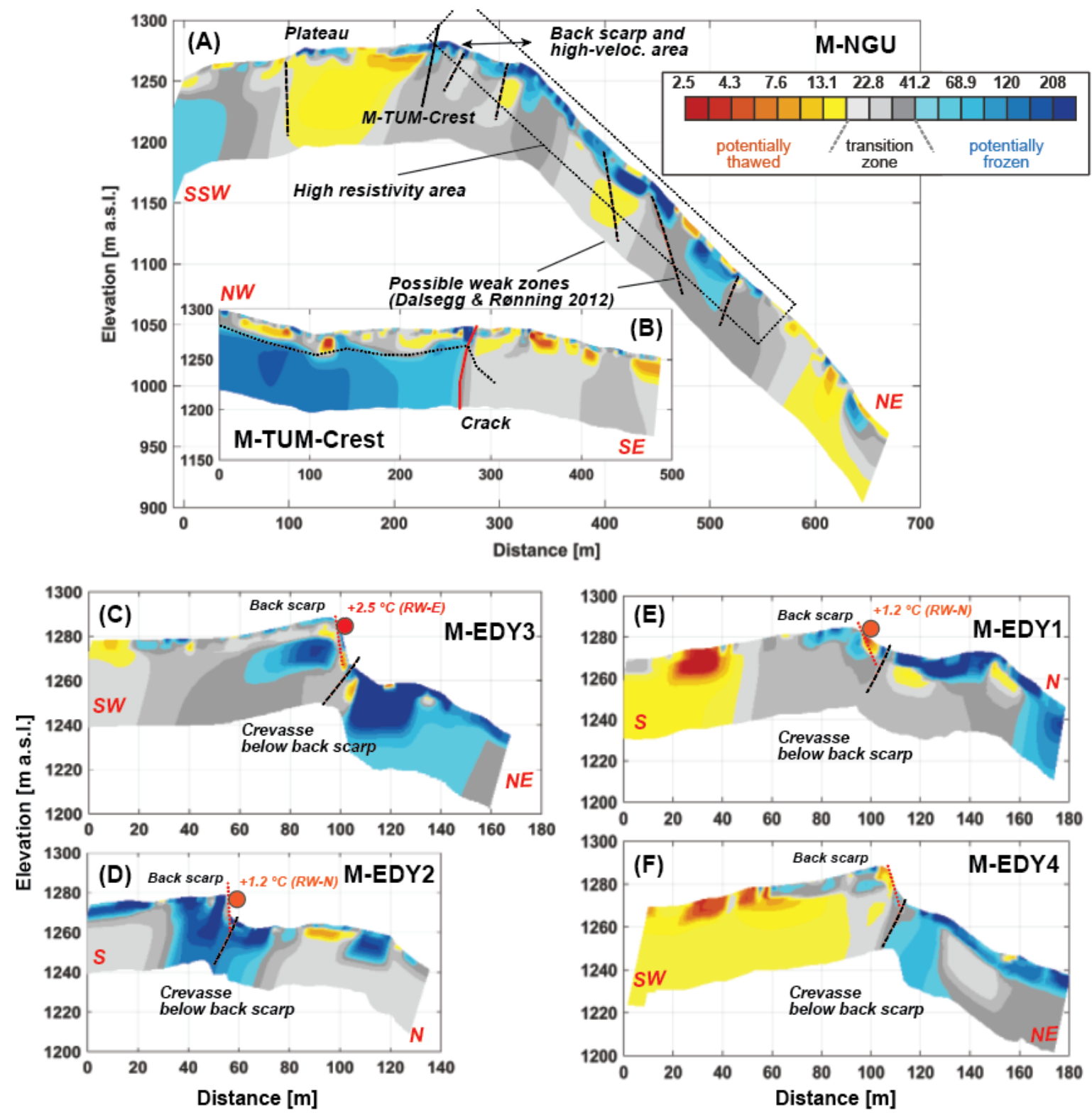

680 Figure 12: ERT surveys over the Mannen instability, for location see Figure 1 and for survey parameters see Table 1. (A) Along-slope profile (M-NGU), based on Dalsegg \& Rønning (2012). The possible weakness zones described in Dalsegg \& Rønning (2012) are indicated by dashed lines. The surface-near high resistivity area is indicated by a box, and may reveal crushed air-filled and well-drained bedrock and may contain permafrost patches (Dalsegg and Rønning, 2012). (B): M-TUM-scarp profile along the rim on the plateau of Mannen above the exposed slip 685 surface. A strong transition of resistivity is indicated by a red line and interpreted as a deep crevasse, maybe waterfilled. (C) to (F) show the ERT profiles (M-EDY1-4) over the rock wall from the plateau into the instability at various location (Figure 1). The circles show the mean annual rock wall temperatures in the two loggers on site. The exposed back fracture below the slip surface is indicated by dashed lines, while the back scarp is indicated by a red line. 


\section{Discussion}

\subsection{Permafrost conditions and recent ground thermal development}

Both the Gámanjunni-3 and the Mannen unstable slopes are considered as high-risk areas and are continuously monitored. The movement was initiated several millennia after deglaciation, thus climate factors have been discussed as an influencing factor (Hilger et al., 2021). The current displacement of the slopes have values exceeding what has been estimated as average during Holocene based on cosmogenic nuclide (CN) dating (Böhme et al., 2019; Hilger et al., 2021), indicating atmospheric warming being a likely influencing factor. For both sites, we hypothesise that permafrost warming and/or degradation might be a substantial explanation. Both study sites are at almost the same elevation (c. $1300 \mathrm{~m}$ a.s.l.), but differ in latitude $\left(62^{\circ} \mathrm{N}\right.$ vs. $\left.69^{\circ} \mathrm{N}\right)$. Based on different permafrost models, permafrost is discontinuous at Gámanjunni-3, while it is sporadic at Mannen (Magnin et al., 2019;Gisnås et al., 2016a;Obu et al., 2019).

At Mannen, at present we do not measure sub-surface RW or GST temperatures below $0^{\circ} \mathrm{C}$ on an annual average, except for shaded location in crevasses (Kristensen et al., 2021). Over the last 140 years, mean annual air temperatures have increased, and since the cooling in 1970s the temperature rise was around $+1.5^{\circ} \mathrm{C}$ (Figure $4 \mathrm{c}$ ). Rock wall temperatures oriented towards north must have had sub-zero surface temperatures during several periods of the last 150 years, indicating the potential of permafrost development in the past in shaded topographic settings (Figure 4c). This confirms the modelling by Magnin et al. (2019), and the results from Kristensen et al (2021) for Veslemannen which can indicate sporadic permafrost zones at Mannen in certain locations such as crevasses, snow-free patches and in shaded locations. It is also well documented that cracks and crevasses in rock walls locally significantly decrease ground temperatures (Magnin et al., 2015a;Hasler et al., 2011). This is also supported by the ERT surveys showing highest resistivity values close to the rock wall and large crevasses (high porosity), which may be partly filled by ice (Figure 12). Unfortunately, there are no observations of ice in the crevasses as in the Jettan rockslide in northern Norway, where permafrost is observed and probably influences seasonal variations in displacement (Blikra and Christiansen, 2014). The mountain plateau of Mannen hardly has permafrost because of very thick and long-lasting snow cover.

For Gámanjunni-3, MAAT have risen over the last 140 years, and since 1880 the rise was around $+1.8^{\circ} \mathrm{C}$. Estimated rock-wall temperatures in all orientations have been mostly negative during the reconstruction period. Since c. 2000, only the south-oriented rock wall showed mean annual temperatures close to or above $0^{\circ} \mathrm{C}$ (Figure $4 \mathrm{c}$ ). This would indicate that permafrost warming and possible degradation might have accelerated since then, which might influence the geotechnical properties of the site. The ERT measurements suggest permafrost at Gámanjunni-3, but resistivity differences between topographic 
aspect and laterally over the plateau indicate changes in ice content and ground temperature including the potential occurrence of taliks (Krautblatter et al., 2010;Gruber and Haeberli, 2007; Gruber and Haeberli, 2009). Those can form during general atmospheric warming, extreme warm years or along water-filled crevasses (Luethi et al., 2017). These processes result in high resistivity variations (Hilbich et al., 2008;Krautblatter and Hauck, 2007;Mollaret et al., 2019). This interplay, together with air and water advection in crevasses produces a complicated thermal pattern, which is not reproduced by our heat flow modelling. The pattern is further highly modulated by snow cover, which in Scandinavian high-mountain settings is highly variable due to wind re-distribution (Gisnås et al., 2014;Gisnås et al., 2016b). Windredistribution of snow is the major source for high spatial variability of surface temperatures (Haberkorn et al., 2015), which can vary with several ${ }^{\circ} \mathrm{C}$ (Gisnås et al., 2014;Marmy et al., 2016;Magnin et al., 2015a;Magnin et al., 2017;Magnin et al., 2015b;Hasler et al., 2011;Haberkorn et al., 2017). However, ice-free north-oriented rock walls show a cooling influence on the surrounding subsurface.

In summary, for both sites, we can expect at least local permafrost conditions, clearly more widespread at Gámanjunni-3 than at Mannen, and a warming with accelerated pace during the last two decades, following similar observations all over Europe (Etzelmüller et al., 2020).

\subsection{Is there a coupling between the slope instability and permafrost dynamics?}

Spatial pattern of movement - The spatial distribution of surface displacement is slightly different at the two sites. At Mannen, relatively high displacement rates of c. $20 \mathrm{~mm} \mathrm{a}^{-1}$ are measured in the upper part of the unstable slope, while low velocities of $<5 \mathrm{~mm} \mathrm{a}^{-1}$ dominate the other parts (Figure 6c). At Gámanjunni-3 displacement rates of $>50 \mathrm{~mm} \mathrm{a}^{-1}$ are registered over most of the mapped rockslide area, with some higher values in the upper part. Maximum velocity values of $>150 \mathrm{~mm} \mathrm{a}^{-1}$ are observed in the southern part of the area, where the rock glacier-like landform is located (Figure 6a-b).

750 Displacement rates, ground temperatures and ERT results were related along the ERT lines G-NVE1-2 and M-NGU1 (Figure 13). At both sites GT is clearly associated with measured resistivity, confirming the lab analysis and our interpretation of possible permafrost at these sites (Figure 13a-b). For Gámanjunni-3 we observe a positive relation between electrical resistivity and displacement rates (more displacement when higher resistivity) and associated lower displacement with higher ground temperatures along the longitudinal profile over the rockslide mass (Figure 13c-d). 

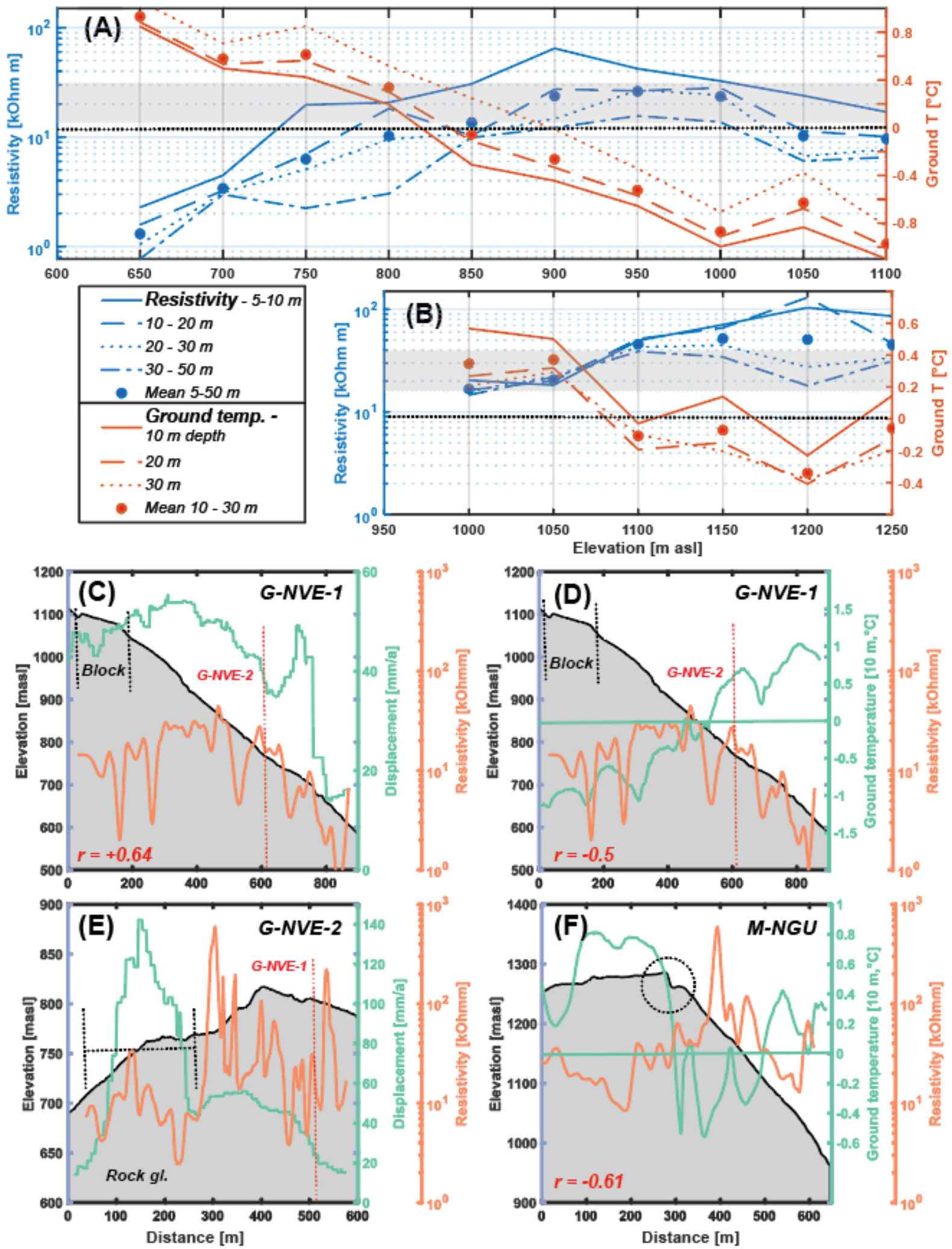
Figure 13 (prev. page ...). Relation between resistivity, modelled ground temperature (GT) and rockslide displacement rates along selected profiles for Gámanjunni-3 and Mannen, binned in $50 \mathrm{~m}$ intervals. At Mannen, poorer InSAR coverage restricted the analysis of velocity-ERT relation. The black dotted line indicates the modelled $0{ }^{\circ} \mathrm{C}$ line, while the grey area indicates the electrical resistivity transition resolved from laboratory analysis (Figure 3). (A) Relation between modelled ground temperature in three depths and extracted electrical resistivity for four different depth areas for G-NVE1. The solid circles display averages over all depths. The graph confirms the transition area for permafrost around $800 \mathrm{~m}$ a.s.l. (B): The same as (A), but for Mannen (M-NGU). Also here there is a higher resistivity with lower temperatures, but the relation is less clear. According to the modelling permafrost can be expected above $1100 \mathrm{~m}$ asl. (C): Relation between elevation, displacement rates and electrical resistivity for G-NVE1. ERT and displacement rates co-vary, with a significant correlation of $r=+0.64$. The red line shows the crossing point for G-NVE-2. (D) G-NVE1. Relation between elevation, modelled GT and electrical resistivity. We observe a negative relation between GT and resistivity $(\mathrm{r}=-0.5)$. The red line shows the crossing point for G-NVE-2.(E) Cross profile G-NVE2 over the rock glacier (dotted line) and rockslide area at c. $700 \mathrm{~m}$ a.s.l. Resistivity is lower and displacements rates are much higher on the rock glacier than on the rockslide part, indicating different modes of movement (see main text for discussion). The red line shows the crossing point for G-NVE-1 (F): M-NGU. Relation between surface altitude, modelled GT and resistivity. We observe a negative relation between GT and resistivity ( $\mathrm{r}=-0.6)$, with lower GT and higher resistivity along the upper part of the steep slope. The location of the back scarp of the unstable area is indicated with a circle.

At Mannen similar observations were made, but are not that clear (Figure 13f). This seems contradictory as permafrost is seen as a stabilising factor for slope stability (Gruber and Haeberli, 2007; Krautblatter et al., 2013). An explanation for this behaviour can be found in e.g. Davies et al. (2001) who found Factorof-safety (FS) values below 1 for ice-filled crevasses close to the melting point, and FS-values at 1 or above when the ice has melted or is very cold. The stability of both, ice in fractures and rock ice interfaces strongly declines with warming temperatures below $0^{\circ} \mathrm{C}$ (Mamot et al., 2018). In addition, migrating water along fractures could favour cryostatic pressure in rocks whose permeability is otherwise too low to allow the migration of unfrozen water to ice surfaces (Murton et al., 2016). Both at Gámanjunni-3 and Mannen possible ice occurences are close to the melting point and thus deformable.

This applies also when analysing the cross profile (G_NVE2) at Gámanjunni-3, which covered both the rock glacier and the rockslide. Here, the geophysical surveys indicate that an unfrozen near-surface layer (ice contents $\sim 0$ in the uppermost $5-10 \mathrm{~m}$ ) overlies frozen areas. Further on, lower resistivity values in 20-30 m depth are measured in the rock glaciers than in the moving part of the rockslide, even if velocities in the rock glacier landform is much higher (Figure 13e). These observations may relate to different processes of movement in the two parts of the instability. While in the rockslide the movement is influenced by possible ice deformation due to inferred higher ice content with depth in this part or block movement below a frozen layer, the rock glacier movement seems governed by movement related to water/ice mixtures close to the melting point, where shear strength is greatly reduced and ice deformation increases (Arenson et al., 2002;Davies et al., 2001) (Cicoira et al., 2019). 
The rock glacier-like landform has markedly higher velocities (Eriksen et al., 2017). Such velocities are common for rock glaciers in alpine environments (Kaab et al., 2007), and often facilitated by a block motion within deforming massive ice body (Arenson et al., 2002;Haeberli et al., 2006;Haeberli et al., 1998) (Cicoira et al., 2019) (Kenner et al., 2017). The ERT measurements show a local resistivity peak under the rock glacier (at c. $120 \mathrm{~m}$ distance, Figure 8b), and GST loggers indicate permafrost presence in the landform (Figures $1 \mathrm{~b}$ and $8 \mathrm{~b}$ ). A rock glacier in the neighbouring valley from Gámanjunni-3 (Adjet rock glacier) had velocity averages increasing from $\sim 4.9$ to $\sim 9.8 \mathrm{~m} \mathrm{a}^{-1}$ (2009-2016) and maximum velocities from $\sim 12$ to $\sim 69 \mathrm{~m} \mathrm{a}^{-1}$ (Eriksen et al., 2018). There, permafrost warming, topographic controls, and increased water access to deeper permafrost layers and internal shear zones have been used to explain the kinematic behaviour at Adjet rock glacier (Eriksen et al., 2018). The higher velocities of the rock glacier in relation to the rockslide mass may indicate higher ice content or warmer ground temperatures, influencing rock glacier kinematics (Kaab et al., 2007; Ikeda et al., 2008) (Cicoira et al., 2019). A possible permafrost degradation and probable thawing at Gámanjunni-3 can reduce the strength and increase the water content in crevasses and cracks in the prolongation of the exposed sliding planes (Bodin et al., 2017). This may result in destabilization of the upper part of the plateau south of Gámanjunni-3 increasing the susceptible volume for worst-case collapse scenario considerably.

For Mannen highest velocities and lowest ERT values are observed below the back scarp and behind the 815 large crevasse building up between the scarp and the unstable moving part of the slope, using GB-InSAR. A similar setting is observed at Jettan at Nordnesfjellet, which lies close to the Gámanjunni site. There, ground ice patches are observed in these cracks, governing movement rates (Blikra and Christiansen, 2014). The ERT measurements indicate very high resistivity values in this zone (>100 $\mathrm{k} \Omega \mathrm{m})$, indicating either air or snow/ice fill. However, there are no direct observations of ice.

820 Temporal movement - The displacement measurements indicate a clear seasonal pattern in Mannen based on GPS and laser measurements, and a possibly seasonal pattern at Gámanjunni-3 based on the GBInSAR time series (Figure 5). At both sites, it seems to be an acceleration during late winter and spring, and lower velocities during summer and fall. Wirz et al (2014) found a maximum displacement at Mattertal (Switzerland) during fall and early winter and a minimum in spring. They point to meltwater infiltration and a phase lag from GST of 2-4 months for landslide displacement. Weber et al. (2017) presented a series of 8 years of fracture kinematics at $3500 \mathrm{~m}$ a.s.l. on the steep and highly fractured Hörnligrat ridge (Matterhorn, Swiss Alps). They showed that, reversible displacements dominate in winter while irreversible enhanced fracture displacements are mainly observed in summer, likely indicating thawing-related processes (e.g., meltwater percolation into fractures). However, this behaviour can strongly differ from one fracture to another as seen at the Aiguille du Midi 3842 a.s.l, France; Guillet 
et al., unpublished results). A similar pattern is observed for Veslemannen (Mannen site, this study), where meltwater infiltration and thawing of seasonal frost along with precipitation episodes are discussed (Kristensen et al., 2021). The instability on the Zugspitze crest (Germany/Austria) shows movements of c. $20 \mathrm{~mm} \mathrm{a}^{-1}$ and highest displacement rates during summer, with a reduction of up to $85 \%$ during the remaining seasons (Mamot et al., 2020). Gischig et al. (2011) found high winter and low summer velocities or the Randa rock slope instability in Switzerland, and no correlation to rain fall. They could reproduce this pattern by thermo-mechanical modelling, where surface temperature governed the variation. In the Jettan site near Gamanjunni-3 Blikra et al. (2014) documented ice in crevasses, and highest velocities during summer, probably caused by melting of ice-patches in crevasses. Vertical movements based on GB-InSAR analysis on the Mannen site indicate seasonal movement ("rock slope breathing"), possibly caused by hydro-geological variations (Rouyet et al., 2017).

The possible higher early spring and summer velocities and lower displacement rates during fall and winter might be related to high water input in the crevasses due to snow melt causing hydraulic/hydrostatic pressures and contributing to melting of ice/snow in crevasses formed during the winter. During summer and fall, the crevasses might be free of ice/snow at the end of the melting season and water infiltration might have less impact. The lower velocities at Mannen during years with lower snow cover (Figure 5f) also supports this interpretation. However, only thermo-mechanical modelling, like applied by Gishig et al (2011) or Mamot et al. (2020), may increase the understanding of how this signal can influence rock mass deformation.

850 In both study sites a long-term Holocene displacement variations seem to be related to climate signals (Hilger et al., 2021). These observations agree also with other studies, e.g. Philips et al (2017) indicate 6000 years old ice in cracks, which failed in 2014, exceeding $100000 \mathrm{~m}^{3}$. Both, permafrost aggradation and degradation act to decrease the stability of intact rock also by featuring fatigue and by critical and subcritical fracture propagation by sites with strongly varying cryostatic and hydrostatic conditions (Draebing and Krautblatter, 2019; Voigtländer et al., 2018). There certainly has been a long-term warming of our study sites since the LIA, and an accelerated warming since c. 2000. Both Hilger et al. (2021) and Böhme et al. (2019) indicated that present atmospheric warming probably has been a factor for the higher displacement rates measured today in comparison to the most of the Holocene. This warming since 2000 has been documented all over Europe (Etzelmüller et al., 2020), and is responsible for permafrost 860 degradation in Norway (Borge et al., 2017), and accelerating in the north (Eriksen et al., 2018; Frauenfelder et al., 2018).

In summary, both sites show corresponding seasonality with increased early summer velocities. Combined with the knowledge of at least discontinuous permafrost to patchy permafrost at the sites, snow and ice melt processes with associated water drainage in cracks are realistic explanations for a possible 
seasonality. There is evidence that the recently measured higher displacement rates in relation to Holocene values (Hilger et al., 2021) may be related to a warmer atmosphere, and can accelerate into the future. The triggering of Veslemannen described in detail in Kristensen et al. (2021) and the acceleration of the Adjet rock glacier (Eriksen et al., 2018) might be some of the first signs. For Gámanjunni-3, a rapid acceleration of the rock-glacier like landform forming the southern part of the rockslide, is possible, as described for various cases in the recent past in northern Norway (Eriksen et al., 2018), in the European Alps (Delaloye et al., 2008) and in Central Asia (Kääb et al., 2020). It could possibly lead to the triggering of secondary rock falls or debris flow, as described elsewhere (Lugon and Stoffel, 2010;Kummert et al., 2018). Thus, thermal conditions influence important processes in massif rockslides, and thus influence landscape development.

\section{Conclusions}

The following conclusions are drawn based on this study:

- Temperature measurements, numerical modelling and geophysical soundings in concerts demonstrates the existence of permafrost at both study sites. At Gámanjunni-3 permafrost seems to extend down to $700 \mathrm{~m}$ asl. today, while at Mannen sporadic pockets of permafrost are possible.

- Surface air and ground temperatures have been warmed significantly since c. 1900 with $+1{ }^{\circ} \mathrm{C}$ and $1.5^{\circ} \mathrm{C}$, and highest temperature are measured and modelled since 2000 at both study sites.

- Displacement rates of Gámanjunni rockslide co-vary significantly with sub-surface resistivity and temperature. Increased displacements rates are associated with lower ground temperatures and higher ground resistivity, possibly related to increased deformation of ground ice in fractures and pores close to the melting point and elevated cryostatic pressure.

- A seasonality of displacement has been observed, with increased velocities during late winter and early summer at both sites. This pattern may be linked to the timing of snow melt and water infiltration, leading to high water pressure.

- The rock glacier associated to the Gámanjunni-3 rockslide show two to three times higher velocities $\left(>100 \mathrm{~m} \mathrm{a}^{-1}\right.$ ) and lower electrical resistivity than the rockslide part. The movement mechanism seems to be different for both systems, and a mixture of water and ice contributing to the rock glacier movement is suggested.

- The permafrost in the study sites has certainly warmed and probably degraded since the LIA, with accelerated pace since c. 2000. This atmospheric and associated permafrost warming might be a factor for the high deformation rates in relation to the Holocene 
https://doi.org/10.5194/esurf-2021-10

Preprint. Discussion started: 9 March 2021

(C) Author(s) 2021. CC BY 4.0 License.

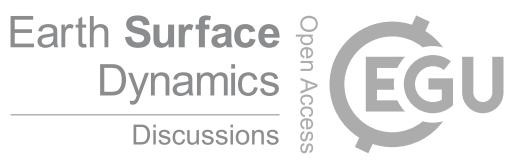

(c) (1)

- A possible permafrost degradation and probable thawing at Gámanjunni-3 may result in destabilization of the upper part of the plateau south of Gámanjunni-3, increasing the susceptible volume for worst-case collapse scenario considerably.

- Our study suggests a coupling of permafrost development and landslide dynamics. 


\section{APPENDIX 1 - Thermal modelling}

The thermal modelling requires a set of parameters and boundary conditions. For our modelling we defined zones with crisp boundaries, defining surface sediment cover, bedrock or fractured bedrock. For

910 each of the zones a set of material properties were defined, following the system in earlier publications (e.g. Westermann et al., 2013). Most cover sediments are quite coarse-grained, with no organic material (Figure A1). For Gámanjunni-3 we used a well-defined geological model to delineate the rockslide (Böhme et al., 2016; Böhme et al., 2019), while for Mannen the instability is much less defined. In the latter surficial material is thin, and bedrock at the surface in the slope, and coarse blocks at the plateau, 915 dominates. For the sensitivity analysis we varied forcing air temperature, snow cover (by changing the $n F$ factor) and the water content, the later only for Gamanjunni because of bedrock dominance with assumed low water content for the Mannen site (Figure A2). Permafrost distribution and geometry varies with these parameters, indicating that reality is probably somewhere in between. Especially for the Mannen site located in the sporadic permafrost zone, the parameter variations show the influence of less 920 snow or cooler SAT on the possible permafrost presence at the site (Figure A2b). 


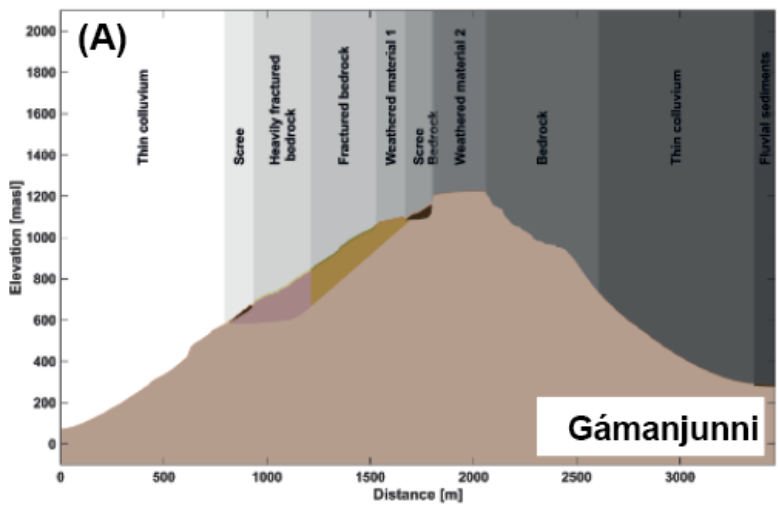

\begin{tabular}{|c|c|c|c|c|c|c|}
\hline Depth [m] & Water & $M$ in . & org. & Air & $\begin{array}{l}\text { MTA } \\
\text { M an. }\end{array}$ & $\begin{array}{l}\text { MTA } \\
\text { Gá m }\end{array}$ \\
\hline \multicolumn{7}{|l|}{ Bedrock } \\
\hline $0.0-2.0$ & 0.05 & 0.95 & 0.00 & 0.00 & 0.05 & 0.05 \\
\hline $2.0-10.0$ & 0.05 & 0.95 & 0.00 & 0.00 & 0.20 & 0.20 \\
\hline $10.0-20.0$ & 0.05 & 0.95 & 0.00 & 0.00 & 0.50 & 0.50 \\
\hline $20.0-100.0$ & 0.05 & 0.95 & 0.00 & 0.00 & 5.00 & 5.00 \\
\hline \multicolumn{7}{|c|}{ Fluvial sediments } \\
\hline $0.0-1.0$ & 0.10 & 0.60 & 0.00 & 0.30 & 0.05 & 0.20 \\
\hline $1.0-2.0$ & 0.40 & 0.60 & 0.00 & 0.00 & 0.05 & 0.20 \\
\hline $2.0-10.0$ & 0.40 & 0.60 & 0.00 & 0.00 & 0.20 & 0.50 \\
\hline $10.0-20.0$ & 0.05 & 0.95 & 0.00 & 0.00 & 0.50 & 5.00 \\
\hline $20.0-100.0$ & 0.05 & 0.95 & 0.00 & 0.00 & 5.00 & 10.00 \\
\hline \multicolumn{7}{|c|}{ Fractured bedrock } \\
\hline $0.0-2.0$ & 0.05 & 0.80 & 0.00 & 0.15 & & 0.05 \\
\hline $2.0-10.0$ & 0.05 & 0.80 & 0.00 & 0.15 & & 0.20 \\
\hline $10.0-20.0$ & 0.10 & 0.90 & 0.00 & 0.00 & & 0.50 \\
\hline$>20.0$ & 0.10 & 0.90 & 0.00 & 0.00 & & 5.00 \\
\hline \multicolumn{7}{|c|}{ Heavily fractured bedrock } \\
\hline $0.0-2.0$ & 0.05 & 0.75 & 0.00 & 0.20 & & 0.05 \\
\hline
\end{tabular}

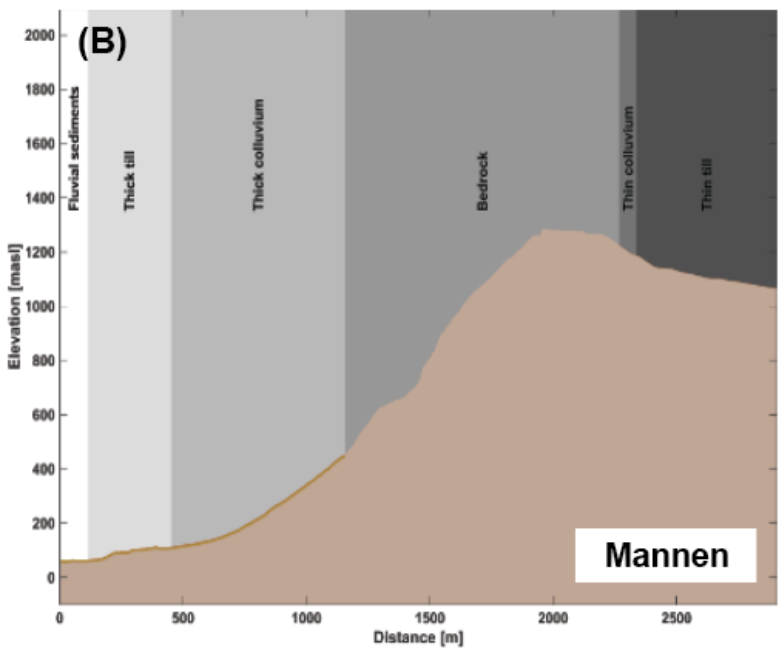

\begin{tabular}{|c|c|c|c|c|c|c|}
\hline & & & & & & \\
\hline $2.0-5.0$ & 0.05 & 0.75 & 0.00 & 0.20 & & 0.20 \\
\hline $5.0-10.0$ & 0.05 & 0.75 & 0.00 & 0.20 & & 0.20 \\
\hline $10.0-20.0$ & 0.15 & 0.80 & 0.00 & 0.05 & & 0.50 \\
\hline$>20.0$ & 0.15 & 0.80 & 0.00 & 0.05 & & 5.00 \\
\hline \multicolumn{7}{|l|}{ Scree } \\
\hline $0.0-2.0$ & 0.02 & 0.40 & 0.00 & 0.58 & & 0.05 \\
\hline $2.0-5.0$ & 0.02 & 0.40 & 0.00 & 0.58 & & 0.20 \\
\hline $5.0-10.0$ & 0.40 & 0.60 & 0.00 & 0.00 & & 0.20 \\
\hline$>10.0$ & 0.40 & 0.60 & 0.00 & 0.00 & & 0.50 \\
\hline \multicolumn{7}{|c|}{ Thick colluvium } \\
\hline $0.0-2.0$ & 0.30 & 0.60 & 0.00 & 0.10 & 0.05 & \\
\hline $2.0-5.0$ & 0.40 & 0.60 & 0.00 & 0.00 & 0.20 & \\
\hline $5.0-10.0$ & 0.40 & 0.60 & 0.00 & 0.00 & 0.20 & \\
\hline $10.0-20.0$ & 0.05 & 0.95 & 0.00 & 0.00 & 0.50 & \\
\hline $20.0-100.0$ & 0.05 & 0.95 & 0.00 & 0.00 & 5.00 & \\
\hline \multicolumn{7}{|c|}{ Thin colluvium } \\
\hline $0.0-1.0$ & 0.30 & 0.60 & 0.00 & 0.10 & 0.05 & 0.20 \\
\hline $1.0-2.0$ & 0.05 & 0.95 & 0.00 & 0.00 & 0.05 & 0.20 \\
\hline $2.0-10.0$ & 0.05 & 0.95 & 0.00 & 0.00 & 0.20 & 0.50 \\
\hline $10.0-20.0$ & 0.05 & 0.95 & 0.00 & 0.00 & 0.50 & 5.00 \\
\hline $20.0-100.0$ & 0.05 & 0.95 & 0.00 & 0.00 & 5.00 & 10.00 \\
\hline \multicolumn{7}{|l|}{ Thick till } \\
\hline $0.0-2.0$ & 0.30 & 0.60 & 0.00 & 0.10 & 0.05 & \\
\hline $2.0-10.0$ & 0.40 & 0.60 & 0.00 & 0.00 & 0.20 & \\
\hline $10.0-20.0$ & 0.05 & 0.95 & 0.00 & 0.00 & 0.50 & \\
\hline
\end{tabular}

Figure A1. The subsurface regions and parametrisation for the 2D thermal modelling for (A) Gámanjunni-3 and (B) Mannen profile. MTA = maximum triangle area, which is a measure describing the spatial resolution of the triangles in the employed finite element method solver. The table shows the stratigraphy chosen for the different regions, along with the depth parametrisation and volumetric contents of water/ice, mineral, organic and air components, following Westermann et al. (2013). 
(B)
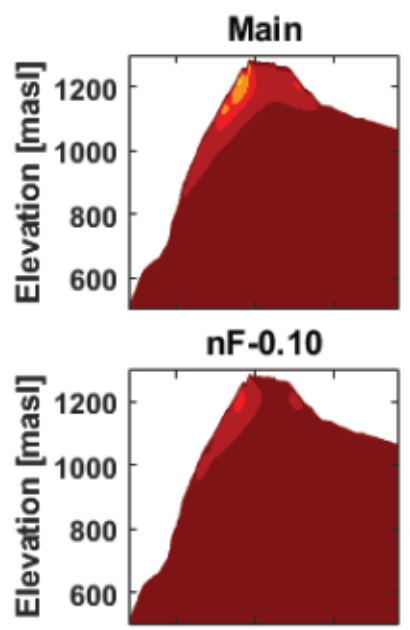

$\mathrm{T}-1.0^{\circ} \mathrm{C}$

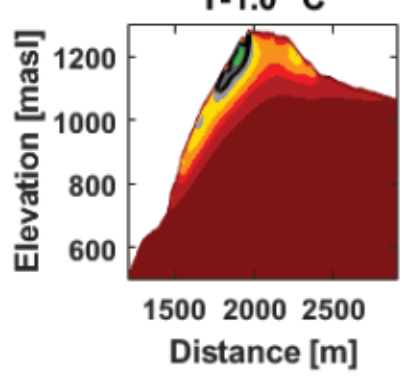

\section{Mannen}

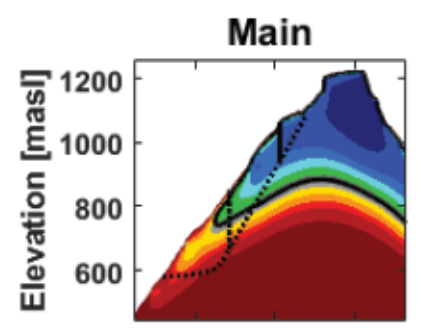

$\mathrm{nF}-\mathbf{0 . 1 0}$

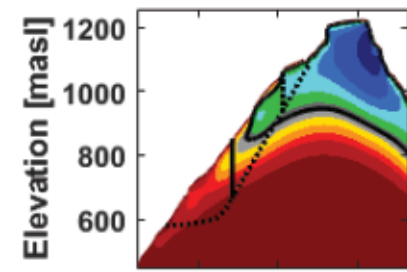

$\mathrm{T}-1.0^{\circ} \mathrm{C}$

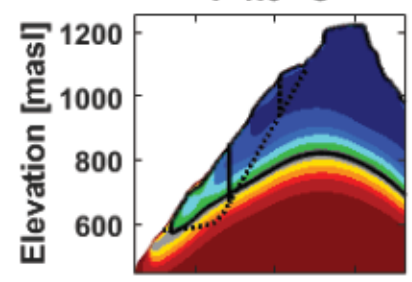

$200 \%$ water

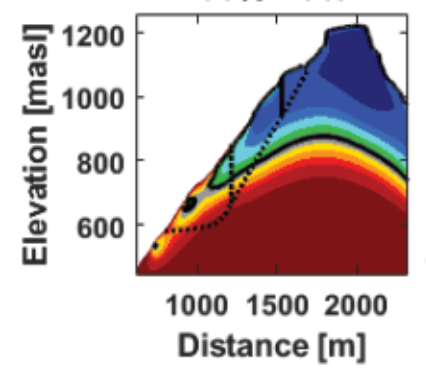

$\mathrm{nF}+\mathbf{0 . 1 0}$

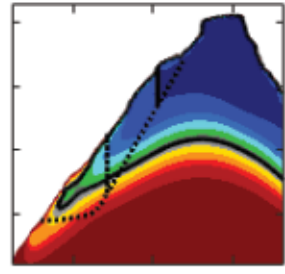

$\mathrm{T}+1.0^{\circ} \mathrm{C}$

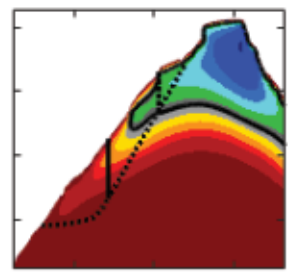

$\mathbf{5 0} \%$ water

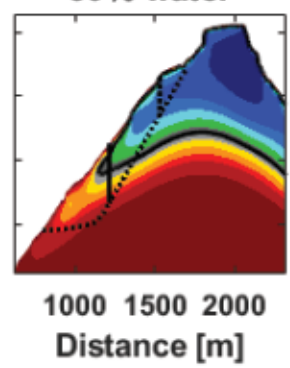

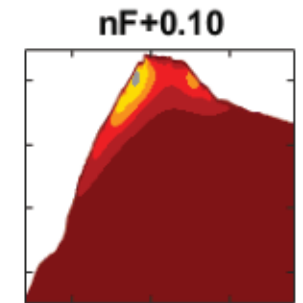

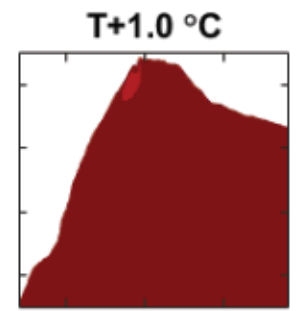

150020002500

Distance [m]

.......... Unstable $-0{ }^{\circ} \mathrm{C}$ isotherm

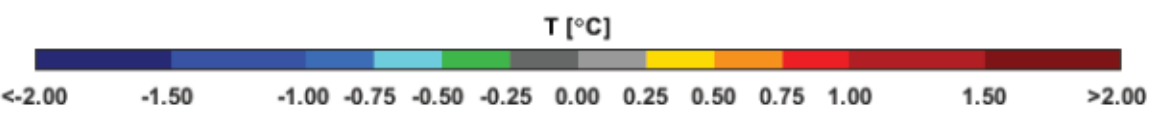

Figure A2. Sensitivity plots for the modelled ground thermal regime of (A) Gámanjunni-3 and (B) Mannen. The "Main" run is the presented run in Figure 7, the subplots show modelled ground temperature in response to changes in $n F$ factor (" $n F+0.1$ " means that $n F$ is increased by 0.1 ; " $n T-0.1$ " means that $n F$ is decreased by 0.1$)$, forcing SAT $\left(" \mathrm{~T}+1{ }^{\circ} \mathrm{C}\right.$ " means that SAT is increased by $1{ }^{\circ} \mathrm{C}$; "T- $1{ }^{\circ} \mathrm{C}$ " means that SAT is decreased by $1{ }^{\circ} \mathrm{C}$ ) and water content in the subsurface (" $50 \%$ water" means that water content is halved and the remaining fraction is added to the mineral fraction; " $200 \%$ water" means that water content is doubled by reducing the mineral fraction). GT and permafrost geometry changes in response to these variations. It is noteworthy at Mannen that only small changes in snow or forcing temperatures would produce considerably more permafrost in the unstable area. Due to limited assumed sediment cover for the Mannen site, we did no sensitivity plot for the water content in bedrock, which is low. 


\section{APPENDIX B - 3D visualisation of ERT profiles}

We projected all ERT profiles in a 3D topographic model in MATLAB (C) Mathworks) (Figures B1 and B2). The inversion was performed with the same parameters, and the colours follow the transition between possible thawed to possible frozen derived from the laboratory analysis (Figure 3). The profiles in the

945 rock walls and steep slopes do not always follow straight lines because of security issues in the field. In the plots we indicated the moving block at Gámanjunni-3, and the plateau crests at both sites. It is clear that the inversion procedures may have produced artefacts at strong topographic transitions. However, the clear patterns described in the main text associated to crevasses and snow-free rock walls are visible. 

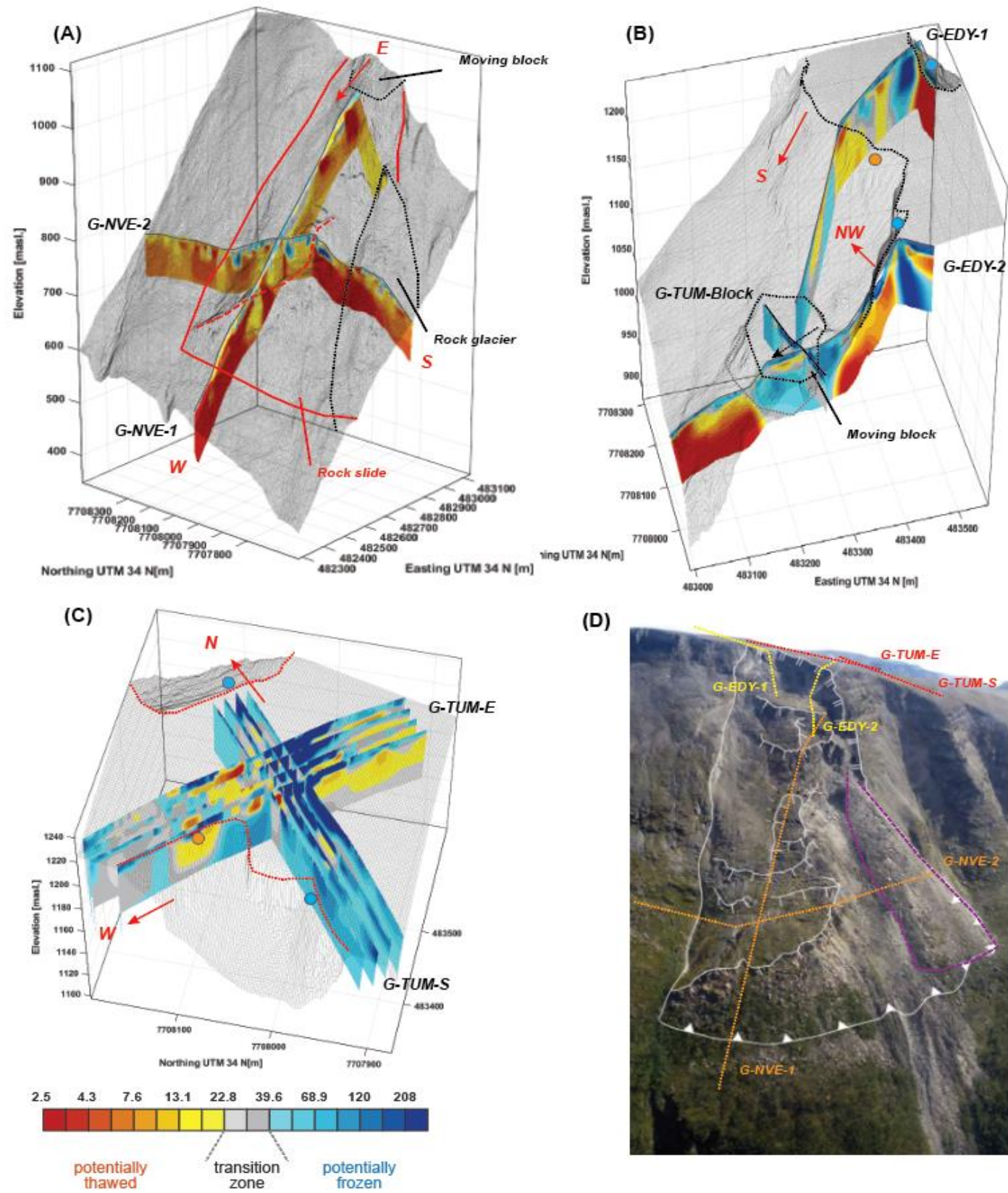

(D)

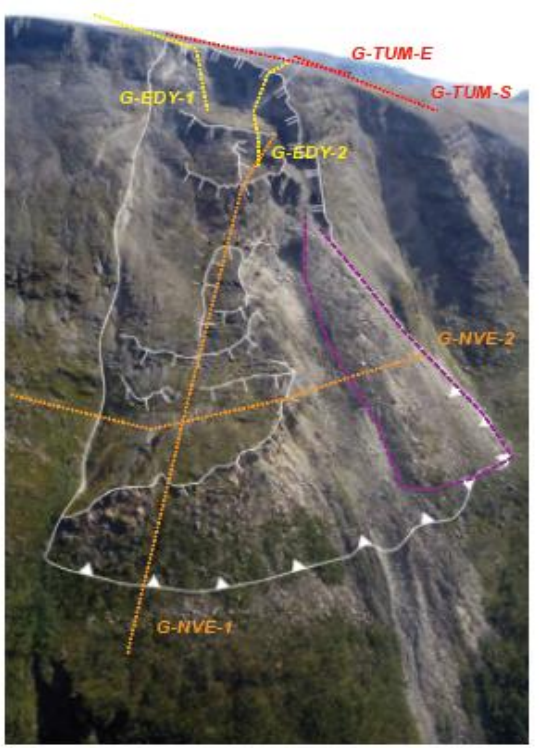

Figure B1. 3D plots showing the ERT profiles in relation to topography for Gámanjunni-3. (A): G-NVE1 and G-NVE2. The rock slide (red) and rock glacier (black) are delineated. The black stippled line indicates the lower limit of the moving block. (B): The rock wall profiles G-EDY1 and 2 and the ERT profile over the moving block (G-TUM-Block). The moving block is indicated by the black line, as is the crest between rock wall and top plateau. The circles show the location of the rock wall loggers (orange $=>0^{\circ} \mathrm{C}$ in annual average, blue $=<0^{\circ} \mathrm{C}$. (C). Quasi 3-D profiles on the plateau (G-TUM-S and E). The red line shows the crest, the circles like in (B). (D): Oblique image of the instability at Gámanjunni-3 as Fig. 2a. The approximate location of the ERT profiles is drawn on the images. (C) NGU. 

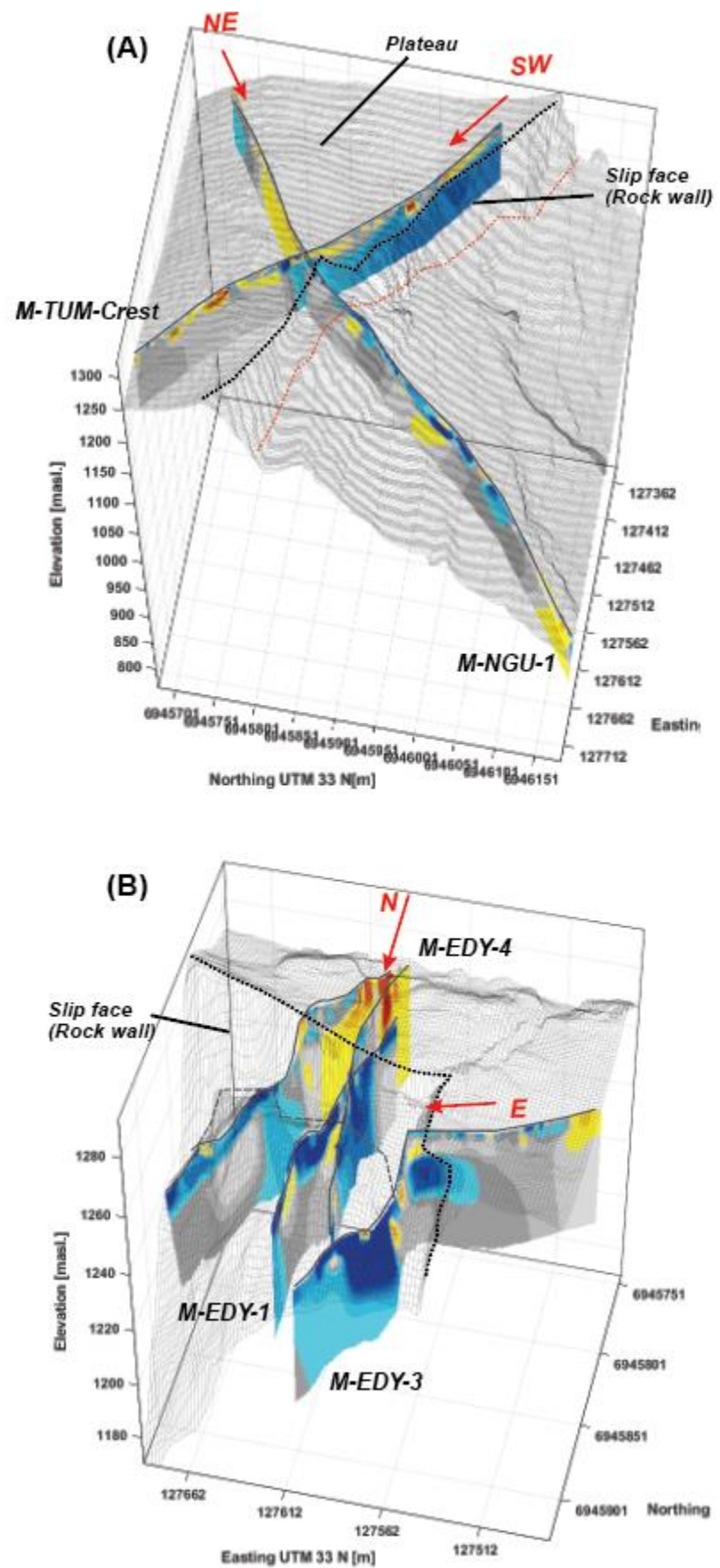

(C)
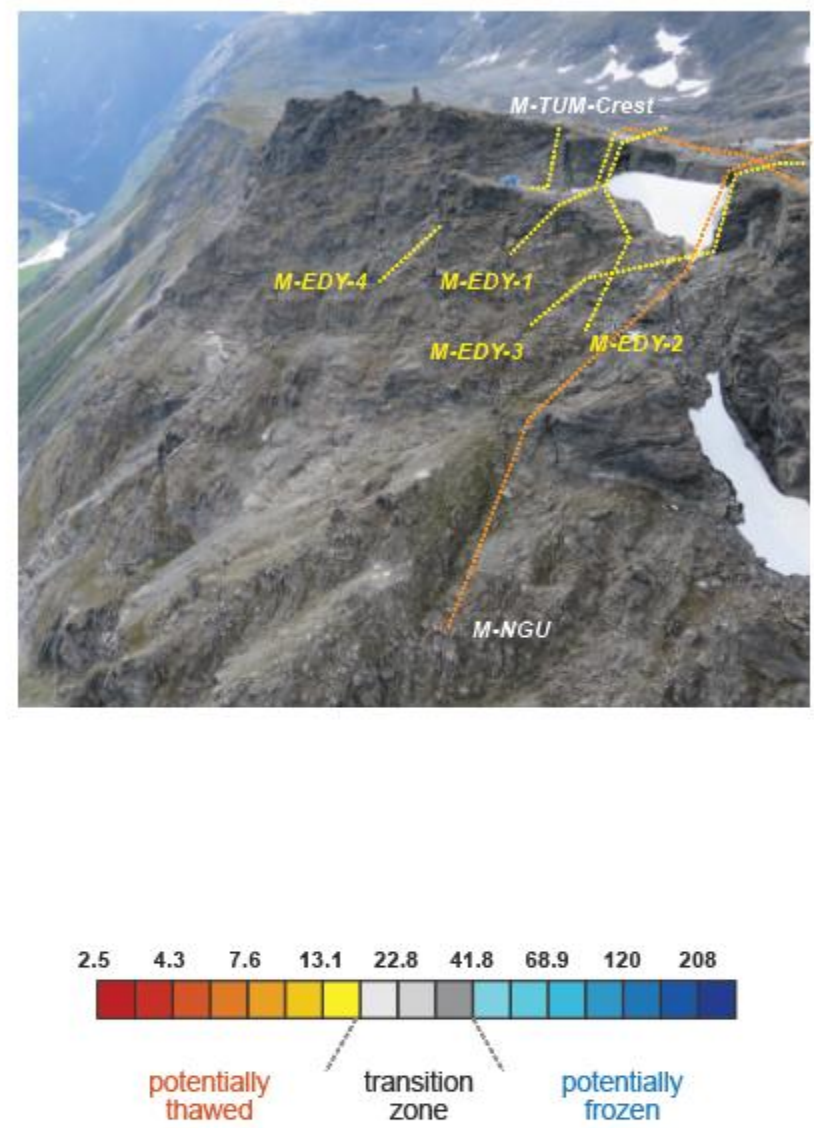

Figure B2. 3D plots showing the ERT profiles in relation to topography for the Mannen instability. The arrows indicate topographic orientation of the profiles. The black stippled line indicate the crest forming the transition between plateau and rock walls. (A): M-TUM-Crest and M-NGU-1. Plateau and rock wall is indicated in the plot. (B): Rock wall ERT profiles MEDY-1 to 4. They deviate from straight lines because of high topography and safety constraints. (C) Oblique air photo $\odot$ P.A. Duvillard), with approximate location of the ERT profile lines. 


\section{APPENDIX C - Background information for the 4PM modelling}

The main principles for the 4Pmodel are (see Hauck et al (2011) and Mewes et al. (2017)):

- The electrical mixing rule (Archie's law which was found empirically by Archie 1942, and later theoretically confirmed by e.g. Sen et al. (1981)),

- An extension to a 4-phase medium of the seismic time-averaged approach for P-wave velocities (modified after Timur (1968)), and

- The necessary assumption that the sum of all volumetric fractions of the ground is equal to one.

Based on these principles, the 4PM uses the following equations to determine the volumetric ice $\left(f_{i}\right)$, water $\left(f_{w}\right)$ and air content $\left(f_{a}\right)$ for a given porosity model $\Phi(x, z)\left(\Phi=1-f_{r}\right.$; $f_{r}$ being the rock content):

$$
\begin{aligned}
& f_{w}=\left(\frac{a \rho_{w}\left(1-f_{r}\right)^{n}}{\rho\left(1-f_{r}\right)^{m}}\right)^{1 / n} \\
& f_{i}=\frac{v_{i} v_{a}}{v_{a}-v_{i}}\left[\frac{1}{v}-\frac{f_{r}}{v_{r}}-\frac{1-f_{r}}{v_{a}}+\left(\frac{a \rho_{w}\left(1-f_{r}\right)^{n}}{\rho\left(1-f_{r}\right)^{m}}\right)^{1 / n}\left(\frac{1}{v_{a}}-\frac{1}{v_{w}}\right)\right] \\
& f_{a}=\frac{v_{i} v_{a}}{v_{i}-v_{a}}\left[\frac{1}{v}-\frac{f_{r}}{v_{r}}+\frac{1}{v_{i}}\left(f_{r}-1\right)-\left(\frac{a \rho_{w}\left(1-f_{r}\right)^{n}}{\rho\left(1-f_{r}\right)^{m}}\right)^{1 / n}\left(\frac{1}{v_{w}}-\frac{1}{v_{i}}\right)\right]
\end{aligned}
$$

where $a$ (= 1 in many applications), $m$ (cementation exponent) and $n$ (saturation exponent) are empirically determined parameters (Archie, 1942), $\rho_{\mathrm{w}}$ is the resistivity of the pore water, $v_{r}, v_{w}, v_{a}, v_{i}$ are the theoretical $\mathrm{P}$-wave velocities of the four components, and $\rho(x, z)$ and $v(x, z)$ are the inverted resistivity and $\mathrm{P}$-wave velocity distributions, respectively.

The pore water resistivity $\left(\rho_{w}\right)$ and the porosity $\Phi$ are the most sensitive for the calculation of the ice and water content (Hauck et al., 2011). As there are often lack of borehole or laboratory data, given exact information around these parameters, there is a uncertainty involved in the modelling approach. This uncertainty has been addressed in several publications, and can be found in e.g. Pellet et al. (Pellet et al., 2016) and Mewes et al. (Mewes et al., 2017). 
While Figure 11 in the main text shows and discusses the results of the 4PM for two profiles at
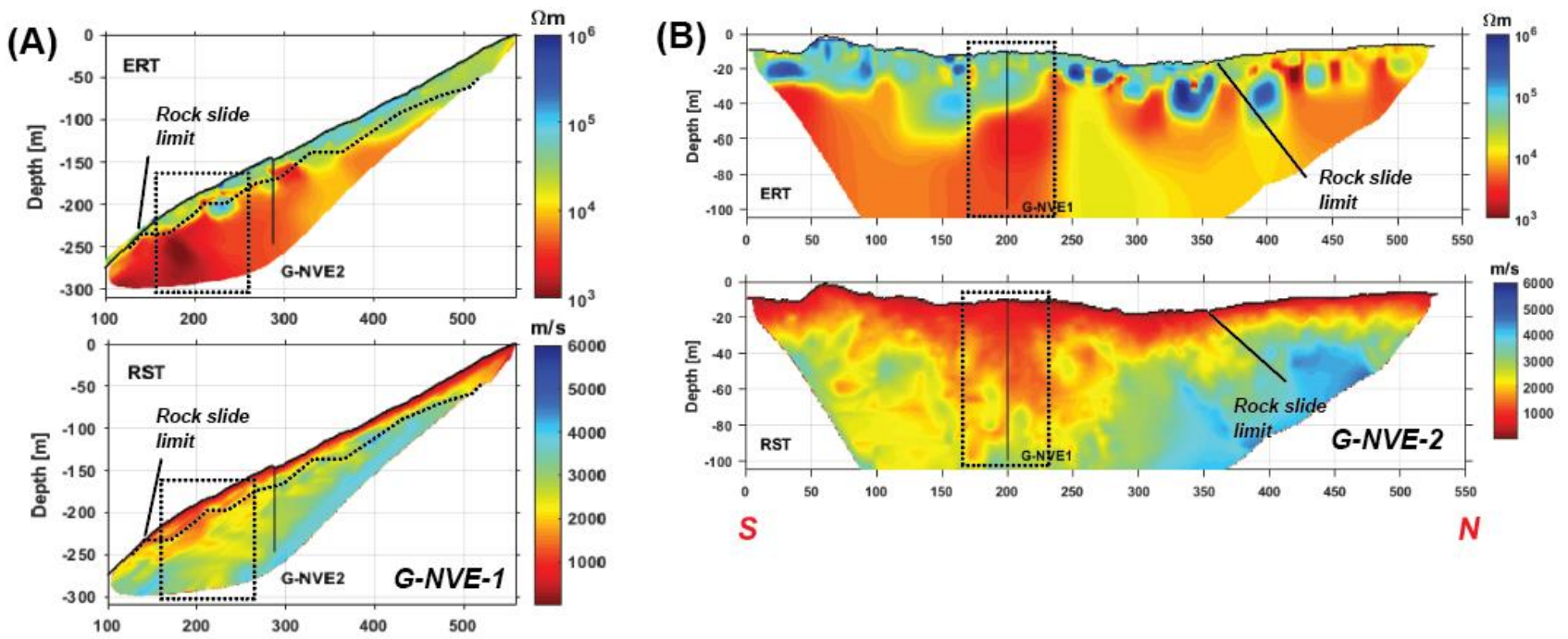

Figure C1: Resistivity and seismic velocities for the 4PM model at Gámanjunni-3 for (A) G-NVE-1 and (B) GNVE-2. Note that the profiles are subsets of G-NVE-1 and -2, and thus shorter than shown in Figure 8 and Figure B1. Note also that the colours for the electrical resistivity do no correspond to the colour scale derived from the laboratory analysis (Figure 3), but are the original results first presented in Hauck and Hilbich (2018). The possible fractures zones mentioned in the manuscript are indicated as a box, while the possible lower permafrost limit is drawn as a line in $(\mathbf{A})$. 


\section{Acknowledgement}

This study was part of the project 'CryoWALL - Permafrost slopes in Norway' (243784/CLE) funded by the Research Council of Norway (RCN). Additional funding was provided by the Norwegian Geological Survey, Trondheim, the Department of Geosciences, University of Oslo, the Norwegian Water and Energy Directorate (NVE), the EDYTEM, Chambéry, France and the Deutsche Forschungsgemeinschaft 1010 (DFG) through the Technical University of Munich (TUM) International Graduate School of Science and Engineering (IGSSE), GSC 81. The TerraSAR-X satellite data set was provided through the German Aerospace Centre (DLR) TerraSAR-X AO projects \#GEO0565 and GEO0764. Jan Steinar Rønning from NGU provided data raw data for the ERT profile M-NGU at Mannen. Thanks to extensive help in field by NVE colleagues, in particular Anders Furuseth and Roald Elvenes at NVE-Kåfjord, and Kjell. R.

1015 Jogerud and Pål R. Hagen Røssevold at NVE-Stranda). Lars Harald Blikra from NVE supported the study extensively. Ove Brynhildsvoll, Jaroslav Obu and Trond Eiken (UiO), Paula Hilger (Høyskolen i Vestlandet, Sogndal) and Regina Pläsken and Maximilian Reinhard (TUM) took part in field work.

\section{Contributions}

$1020 \mathrm{BE}$ took the initiative for the study, and coordinated the synthesis of the various data sets. He wrote the first drafts of the manuscript, and designed most of the figures. JC carried out the numerical modelling of the ground thermal regime at both sites, provided background information and modelling results and developed visualisation tools or the ERT profiles. SW developed much of the principles of the numerical modelling code, and supervised the analysis. FM coordinated and participated in the field investigation of the ground temperature and ERT rock wall surveys at both sites. PAD and EM participated at the ERT surveys at Mannen and PAD and LR at Gámanjunni-3. AA, LK and IS contributed with on-site knowledge, interpretation and displacement data from laser, GPS and GB-InSAR, on behalf of NVE. BJ, JL and MK contributed with the laboratory analysis of the bedrock samples at the Technical University of Munich (Germany), and ERT profiles conducted in field at both sites. RH and MB from NGU contributed with a structural-geological model of the sites. CHa and CHi from the University of Fribourg, Switzerland, applied the 4-phase-model and submitted a report from the two long profiles at Gámanjunni. They also commented and improved the inversion and interpretation of all the other ERT profiles. HE provided and interpreted the TerraSAR-X data from Gámanjunni, along with ground temperature logger data. All authors contributed actively to the final versions of the manuscript.

Competing interests: The authors declare that they have no conflict of interest. 


\section{References}

1040 Arenson, L., Hoelzle, M., and Springman, S.: Borehole deformation measurements and internal structure of some rock glaciers in Switzerland, Permafrost and Periglacial Processes, 13, 117-135, 2002.

Bardi, F., Raspini, F., Ciampalini, A., Kristensen, L., Rouyet, L., Lauknes, T. R., Frauenfelder, R., and Casagli, N.: Space-borne and ground-based InSAR data integration: the Åknes test site, Remote Sensing, 8, 237, 2016.

Barker, R.: Depth of investigation of collinear symmetrical four-electrode arrays, Geophysics, 54, 1031-1037, 1989.

Blikra, L., Majala, G., Anda, E., Berg, H., Eikenæs, O., Helgås, G., Oppikofer, T., Hermanns, R., and Böhme, M.: Fare-og risikoklassifisering av ustabile fjellparti-Faresoner, arealhåndtering og tiltak, Norges Geologiske Undersøkelser (NGU), 47, 2016.

Blikra, L. H., and Christiansen, H. H.: A field-based model of permafrost-controlled rockslide deformation in northern Norway, Geomorphology, 208, 34-49, http://dx.doi.org/10.1016/j.geomorph.2013.11.014, 2014.

Bodin, X., Krysiecki, J.-M., Schoeneich, P., Le Roux, O., Lorier, L., Echelard, T., Peyron, M., and Walpersdorf, A.: The 2006 Collapse of the Bérard Rock Glacier (Southern French Alps), Permafrost and Periglacial Processes, 28, 209-223, https://doi.org/10.1002/ppp.1887, 2017.

Böhme, M., Bunkholt, H., Dehls, J., Oppikofer, T., Hermanns, R., Dalsegg, E., Kristensen, L., Lauknes, T., and Eriksen, H.: Geologisk modell og fare-og risikoklassifisering av det ustabile fjellpartiet Gamanjunni 3 i Manndalen, Troms, NGU Rapport, 64, 2016.

Böhme, M., Hermanns, R., Gosse, J., Hilger, P., Eiken, T., Lauknes, T., and Dehls, J.: Comparison of monitoring data with paleo-slip rates: Cosmogenic nuclide dating detects acceleration of a rockslide, Geology, 47, 339-342, 2019.

1060 Borge, A. F., Westermann, S., Solheim, I., and Etzelmuller, B.: Strong degradation of palsas and peat plateaus in northern Norway during the last 60 years, The Cryosphere, 11, 1-16, http://dx.doi.org10.5194/tc-11-1$\underline{2017}, 2017$.

Brenning, A., Gruber, S., and Hoelzle, M.: Sampling and statistical analyses of BTS measurements, Permafrost and Periglacial Processes, 16, 383-394, 2005.

1065 Cicoira, A., Beutel, J., Faillettaz, J., and Vieli, A.: Water controls the seasonal rhythm of rock glacier flow, Earth and Planetary Science Letters, 528, 115844, 2019.

Crosta, G., Agliardi, F., Rivolta, C., Alberti, S., and Dei Cas, L.: Long-term evolution and early warning strategies for complex rockslides by real-time monitoring, Landslides, 14, 1615-1632, 2017.

Dabrowski, M., Krotkiewski, M., and Schmid, D. W.: MILAMIN: MATLAB-based finite element method solver for large problems, Geochemistry, Geophysics, Geosystems, 9, Q04030, 10.1029/2007GC001719, 2008.

Dahle, H., Anda, E., Saintot, A., and Sætre, S.: Faren for fjellskred fra fjellet Mannen i Romsdalen, NGU, Trondheim, 2008.

Dahle, H., Saintot, A., Blikra, L., and Anda, E.: Geofagleg oppfølging av ustabilt fjellparti ved Mannen i Romsdalen, NGU report, 2010. 
Dahlin, T., and Zhou, B.: A numerical comparison of 2D resistivity imaging with 10 electrode arrays, Geophysical prospecting, 52, 379-398, 2004.

Dalsegg, E., and Rønning, J. S.: Geofysiske målinger på Mannen i Rauma kommune, Møre og Romsdal, Norwegian Geological Survey (NGU) report, 2012.

Davidson, E. A., and Janssens, I. A.: Temperature sensitivity of soil carbon decomposition and feedbacks to climate change, Nature, 440, 165, 2006.

Davies, M. C. R., Hamza, O., and Harris, C.: The effect of rise in mean annual temperature on the stability of rock slopess containing ice-filled discontinuities, Permafrost and Periglacial Processes, 12, 137-144, 2001.

Delaloye, R., Perruchoud, E., Avian, M., Kaufmann, V., Bodin, X., Hausmann, H., Ikeda, A., Kääb, A., KellererPirklbauer, A., and Krainer, K.: Recent interannual variations of rock glacier creep in the European Alps, 2008.

Draebing, D., and Krautblatter, M.: The efficacy of frost weathering processes in alpine rockwalls, Geophysical Research Letters, 46, 6516-6524, 2019.

Eriksen, H., Rouyet, L., Lauknes, T., Berthling, I., Isaksen, K., Hindberg, H., Larsen, Y., and Corner, G.: Recent acceleration of a rock glacier complex, Adjet, Norway, documented by 62 years of remote sensing observations, Geophysical Research Letters, 45, 8314-8323, 2018.

Eriksen, H. Ø., Lauknes, T. R., Larsen, Y., Corner, G. D., Bergh, S. G., Dehls, J., and Kierulf, H. P.: Visualizing and interpreting surface displacement patterns on unstable slopes using multi-geometry satellite SAR interferometry (2D InSAR), Remote Sens Environ, 191, 297-312, 2017.

Eriksen, H. Ø.: Instrumentation and temperature data (2013-2017), Gámanjunni 3 rockslide and rock glacier, Manndalen, Troms., NORUT, Tromsø9/2018, 2018.

Etzelmüller, B., Guglielmin, M., Hauck, C., Hilbich, C., Hoelzle, M., Isaksen, K., Noetzli, J., Oliva, M., and Ramos, M.: Twenty years of European mountain permafrost dynamics - the PACE legacy, Environ Res Lett, 15, 104070, 2020.

Evans, S. G., and DeGraff, J. V.: Catastrophic landslides: effects, occurrence, and mechanisms, Geological Society of America, 2002.

Farbrot, H., Isaksen, K., Etzelmuller, B., and Gisnas, K.: Ground Thermal Regime and Permafrost Distribution under a Changing Climate in Northern Norway, Permafrost and Periglacial Processes, 24, 20-38, Doi 10.1002/Ppp.1763, 2013.

Fischer, L., Purves, R. S., Huggel, C., Noetzli, J., and Haeberli, W.: On the influence of topographic, geological and cryospheric factors on rock avalanches and rockfalls in high-mountain areas, Nat Hazard Earth Sys, 12, 241-254, 10.5194/nhess-12-241-2012, 2012.

Frauenfelder, R., Isaksen, K., Lato, M. J., and Noetzli, J.: Ground thermal and geomechanical conditions in a permafrost-affected high-latitude rock avalanche site (Polvartinden, northern Norway), The Cryosphere, $12,1531-1550,2018$.

1110 GeoExpert: Gamanjunni rock mass movement site / Kåfjord, Norway.Hybrid seismic mapping of the subsurface structures., Embrach, Austria, 2016. 
Gischig, V. S., Moore, J. R., Evans, K. F., Amann, F., and Loew, S.: Thermomechanical forcing of deep rock slope deformation: 2. The Randa rock slope instability, Journal of Geophysical Research: Earth Surface, 116, 2011.

1115 Gisnas, K., Etzelmuller, B., Farbrot, H., Schuler, T. V., and Westermann, S.: CryoGRID 1.0: Permafrost Distribution in Norway estimated by a Spatial Numerical Model, Permafrost and Periglacial Processes, 24, 2-19, Doi 10.1002/Ppp.1765, 2013.

Gisnås, K., Westermann, S., Schuler, T. V., Litherland, T., Isaksen, K., Boike, J., and Etzelmüller, B.: A statistical approach to represent small-scale variability of permafrost temperatures due to snow cover, The Cryosphere, 8, 2063-2074, 10.5194/tc-8-2063-2014, 2014.

Gisnås, K., Etzelmüller, B., Lussana, C., Hjort, J., Sannel, B., Isaksen, K., Westermann, S., Kuhry, P., Christiansen, H. H., Frampton, A., and Åkermann, J.: Permafrost map for Norway, Sweden and Finland, Permafrost and Periglacial Processes, 20, http://dx.doi.org10.1002/ppp.1922, 2016a.

Gisnås, K., Westermann, S., Schuler, T., Melvold, K., and Etzelmüller, B.: Small-scale variation of snow in a regional permafrost model, The Cryosphere, 10, 1201-1215, http://dx.doi.org10.5194/tc-10-1201-2016, $2016 b$.

Gruber, S., Hoelzle, M., and Haeberli, W.: Rock-wall temperatures in the Alps: Modelling their topographic distribution and regional differences, Permafrost and Periglacial Processes, 15, 299-307, Doi 10.1002/Ppp.501, 2004.

Gruber, S., and Haeberli, W.: Permafrost in steep bedrock slopes and its temperature-related destabilization following climate change, Journal of Geophysical Research-Earth Surface, 112, -, Artn F02s18 Doi 10.1029/2006jf000547, 2007.

Gruber, S., and Haeberli, W.: Mountain permafrost, in: Permafrost soils, Springer, 33-44, 2009.

Geological Survey of Austria (GSA): Electrical Resistivity Tomography at Gamanjunni, Troms, Norway, GSA, Vienna, 12, 2016.

Haberkorn, A., Hoelzle, M., Phillips, M., and Kenner, R.: Snow as a driving factor of rock surface temperatures in steep rough rock walls, Cold Reg Sci Technol, 118, 64-75, 2015.

Haberkorn, A., Wever, N., Hoelzle, M., Phillips, M., Kenner, R., Bavay, M., and Lehning, M.: Distributed snow and rock temperature modelling in steep rock walls using Alpine3D, Cryosphere, 11, 585-607, 2017.

1140 Haeberli, W.: Die Basis Temperatur der winterlichen Schneedecke als möglicher Indikator für die Verbreitung von Permafrost., Zeitschrift für Gletscherkunde und Glazialgeologie, 9, 221-227, 1973.

Haeberli, W., Hoelzle, M., Kaeaeb, A., Keller, F., Vonder, M. D., and Wagner, S.: Ten years after drilling through the permafrost of the active rock glacier Murtel, Eastern Swiss Alps; answered questions and new perspectives, in: Permafrost; seventh international conference, proceedings., edited by: Lewkowicz, A. G., and Allard, M., Collection Nordicana, Centre d'Etudes Nordiques, Universite Laval, Quebec, PQ, Canada, 403-410, 1998.

Haeberli, W., Hallet, B., Arenson, L., Elconin, R., Humlun, O., Kaab, A., Kaufmann, V., Ladanyi, B., Matsuoka, N., Springman, S., and Vonder Muhll, D.: Permafrost creep and rock glacier dynamics, Permafrost and Periglacial Processes, 17, 189-214, 10.1002/ppp.561, 2006. 
Haeberli, W., Noetzli, J., Arenson, L., Delaloye, R., Gaertner-Roer, I., Gruber, S., Isaksen, K., Kneisel, C., Krautblatter, M., and Phillips, M.: Mountain permafrost: development and challenges of a young research field, J Glaciol, 57, 1043-1058, 2010.

Hasler, A., Gruber, S., Font, M., and Dubois, A.: Advective Heat Transport in Frozen Rock Clefts: Conceptual Model, Laboratory Experiments and Numerical Simulation, Permafrost and Periglacial Processes, 22, 378389, 10.1002/ppp.737, 2011.

Hauck, C.: Frozen ground monitoring using DC resistivity tomography, Geophysical Research Letters, 29, 12-11$12-14,2002$.

Hauck, C., Isaksen, K., Vonder Mühll, D., and Sollid, J. L.: Geophysical surveys designed to delineate the altitudinal limit of mountain permafrost: an example from Jotunheimen, Norway, Permafrost and Periglacial Processes, 15, 191-205, 2004.

Hauck, C., Boettcher, M., and Maurer, H.: A new model for estimating subsurface ice content based on combined electrical and seismic data sets, Cryosphere, 5, 453-468, 10.5194/tc-5-453-2011, 2011.

Hauck, C., and Hilbich, C.: 4-phase model simulations Gamanjunni, Norway, 2018. NVE report, avalable on https://www.nve.no/media/7646/report-gamanjunni-4phasemodel-unifr-2018.pdf, NVE, Oslo, 2018.

Henderson, I., and Saintot, A.: Fjellskredundersøkelser i Møre og Romsdal, NGU report, 2007.

Henderson, I. H., and Saintot, A.: Regional spatial variations in rockslide distribution from structural geology ranking: an example from Storfjorden, western Norway, Geological Society, London, Special Publications, 351, 79-95, 2011.

Hermanns, R., Blikra, L., Anda, E., Saintot, A., Dahle, H., Oppikofer, T., Fischer, L., Bunkholt, H., Böhme, M., Dehls, J., Lauknes, T., Redfield, T., Osmundsen, P., and Eiken, T.: Systematic Mapping of Large Unstable Rock Slopes in Norway, in: Landslide Science and Practice, edited by: Margottini, C., Canuti, P., and Sassa, K., Springer Berlin Heidelberg, 29-34, 2013a.

Hermanns, R. L., Dahle, H., Bjerke, P. L., Crosta, G. B., Anda, E., Blikra, L. H., Saintot, A., and Longva, O.: Rockslide Dams in Møre og Romsdal County, Norway, in: Landslide Science and Practice, Springer, 3-12, $2013 b$.

Hermanns, R. L., Oppikofer, T., Roberts, N. J., and Sandøy, G.: Catalogue of historical displacement waves and landslide-triggered tsunamis in Norway, in: Engineering geology for society and territory, edited by: Lollino, G., Springer, 2014.

Hilbich, C., Hauck, C., Hoelzle, M., Scherler, M., Schudel, L., Voelksch, I., Muehll, D. V., and Maeusbacher, R.: Monitoring mountain permafrost evolution using electrical resistivity tomography: A 7-year study of seasonal, annual, and long-term variations at Schilthorn, Swiss Alps, Journal of Geophysical ResearchEarth Surface, 113, -, 10.1029/2007JF000799 2008.

Hilger, P., Hermanns, R. L., Gosse, J. C., Jacobs, B., Etzelmüller, B., and Krautblatter, M.: Multiple rock-slope failures from Mannen in Romsdal Valley, western Norway, revealed from Quaternary geological mapping and 10Be exposure dating, The Holocene, 28, 1841-1854, 2018.

Hilger, P., Hermanns, R., Czekirda, J., Myhra, K. S., Gosse, J., and Etzelmüller, B.: Permafrost as a first order control on long-term rock-slope deformation in the (Sub-)Arctic, Quaternary Science Reviews, 251, $106718,2021$. 
Hjort, J., Karjalainen, O., Aalto, J., Westermann, S., Romanovsky, V. E., Nelson, F. E., Etzelmüller, B., and Luoto, M.: Degrading permafrost puts Arctic infrastructure at risk by mid-century, Nature Communications, 9 , 5147, 10.1038/s41467-018-07557-4, 2018.

Hughes, A. L., Gyllencreutz, R., Lohne, Ø. S., Mangerud, J., and Svendsen, J. I.: The last Eurasian ice sheets-a chronological database and time-slice reconstruction, DATED-1, Boreas, 45, 1-45, 2016.

Ikeda, A., Matsuoka, N., and Kaab, A.: Fast deformation of perennially frozen debris in a warm rock glacier in the Swiss Alps: An effect of liquid water, Journal of Geophysical Research-Earth Surface, 113, 10.1029/2007JF000859, 2008.

Isaksen, K., Holmlund, P., Sollid, J. L., and Harris, C.: Three deep alpine-permafrost boreholes in Svalbard and Scandinavia, Permafrost and Periglacial Processes, 12, 13-25, 2001.

Isaksen, K., Hauck, C., Gudevang, E., Ødegård, R. S., and Sollid, J. L.: Mountain permafrost distribution on Dovrefjell and Jotunheimen, southern Norway, based on BTS and DC resistivity tomography data, Norsk Geografisk Tidsskrift, 56, 122-136, 2002.

Jia, H., Xiang, W., and Krautblatter, M.: Quantifying rock fatigue and decreasing compressive and tensile strength after repeated freeze-thaw cycles, Permafrost and Periglacial processes, 26, 368-377, 2015.

Kaab, A., Frauenfelder, R., and Roer, I.: On the response of rockglacier creep to surface temperature increase, Global and Planetary Change, 56, 172-187, 10.1016/j.gloplacha.2006.07.005, 2007.

Kääb, A., Strozzi, T., Bolch, T., Caduff, R., Trefall, H., Stoffel, M., and Kokarev, A.: Inventory, motion and acceleration of rock glaciers in Ile Alatau and Kungöy Ala-Too, northern Tien Shan, since the 1950s, The Cryosphere Discussions, 1-37, 2020.

Kenner, R., Phillips, M., Beutel, J., Hiller, M., Limpach, P., Pointner, E., and Volken, M.: Factors controlling velocity variations at short-term, seasonal and multiyear time scales, Ritigraben rock glacier, Western Swiss Alps, Permafrost and Periglacial Processes, 28, 675-684, 2017.

Krautblatter, M., and Hauck, C.: Electrical resistivity tomography monitoring of permafrost in solid rock walls, Journal of Geophysical Research-Earth Surface, 112, -, 2007.

Krautblatter, M., Verleysdonk, S., Flores-Orozco, A., and Kemna, A.: Temperature-calibrated imaging of seasonal changes in permafrost rock walls by quantitative electrical resistivity tomography (Zugspitze, German/Austrian Alps), Journal of Geophysical Research-Earth Surface, 115, -, 2010.

Krautblatter, M., Funk, D., and Günzel, F. K.: Why permafrost rocks become unstable: a rock-ice-mechanical model in time and space, Earth Surface Processes and Landforms, 38, 876-887, 10.1002/esp.3374, 2013.

Kristensen, L., Czekirda, J., Nicolet, P., Etzelmüller, B., Abellan, A., Skrede, I., Blikra, L. H., Pullarello, J., Penna, I., and Oldani, S.: Movements, failure and climatic control of the Veslemannen rockslide, Western Norway, Landslides, 2021.

Kummert, M., Delaloye, R., and Braillard, L.: Erosion and sediment transfer processes at the front of rapidly moving rock glaciers: Systematic observations with automatic cameras in the western Swiss Alps, Permafrost and Periglacial Processes, 29, 21-33, 2018.

1225 Leinauer, J.: Controls of permafrost-related rock slope instabilities exemplified at the Gamanjunni (Norway), MSc, Engineering Geology \& Hydrogeology, Technical University of Munich, Munchen, 2017. 
Lewkowicz, A. G., Bonnaventure, P. P., Smith, S. L., and Kuntz, Z.: Spatial and Thermal Characteristics of Mountain Permafrost, Northwest Canada, Geografiska Annaler Series a-Physical Geography, 94A, 195213, DOI 10.1111/j.1468-0459.2012.00462.x, 2012.

Loke, M. H., and Barker, R. D.: Rapid least-squares inversion of apparent resistivity pseudosections using a quasiNewton method., Geophysical Prospecting, 44, 131-152, 1995.

Luethi, R., Phillips, M., and Lehning, M.: Estimating non-conductive heat flow leading to intra-permafrost Talik formation at the Ritigraben Rock Glacier (Western Swiss Alps), Permafrost and Periglacial Processes, 28, 183-194, 2017.

Lugon, R., and Stoffel, M.: Rock-glacier dynamics and magnitude-frequency relations of debris flows in a highelevation watershed: Ritigraben, Swiss Alps, Global and Planetary Change, 73, 202-210, 2010.

Lussana, C., Saloranta, T., Skaugen, T., Magnusson, J., Tveito, O. E., and Andersen, J.: seNorge2 daily precipitation, an observational gridded dataset over Norway from 1957 to the present day, Earth System Science Data, 10, 235, 2018.

Magnin, F., Deline, P., Ravanel, L., Noetzli, J., and Pogliotti, P.: Thermal characteristics of permafrost in the steep alpine rock walls of the Aiguille du Midi (Mont Blanc Massif, $3842 \mathrm{~m}$ asl), The Cryosphere, 9, 109-121, $2015 \mathrm{a}$.

Magnin, F., Krautblatter, M., Deline, P., Ravanel, L., Malet, E., and Bevington, A.: Determination of warm, sensitive permafrost areas in near-vertical rockwalls and evaluation of distributed models by electrical resistivity tomography, Journal of Geophysical Research: Earth Surface, 120, 745-762, 2015b.

Magnin, F., Josnin, J.-Y., Ravanel, L., Pergaud, J., Pohl, B., and Deline, P.: Modelling rock wall permafrost degradation in the Mont Blanc massif from the LIA to the end of the 21st century, The Cryosphere, 11, 1813, 2017.

Magnin, F., Etzelmüller, B., Westermann, S., Isaksen, K., Hilger, P., and Hermanns, R. L.: Permafrost distribution in steep rock slopes in Norway: measurements, statistical modelling and implications for geomorphological processes, Earth Surface Dynamics, 7, 1019-1040, 2019.

Mamot, P., Weber, S., Schröder, T., and Krautblatter, M.: A temperature- and stress-controlled failure criterion for ice-filled permafrost rock joints, The Cryosphere, 12, 3333-3353, 10.5194/tc-12-3333-2018, 2018.

Mamot, P., Weber, S., Schröder, T., and Krautblatter, M.: A temperature- and stress-controlled failure criterion for ice-filled permafrost rock joints, The Cryosphere, 2019.

Mamot, P., Weber, S., Eppinger, S., and Krautblatter, M.: Stability assessment of degrading permafrost rock slopes based on a coupled thermo-mechanical model, Earth Surf. Dynam. Discuss., 2020, 1-45, 10.5194/esurf2020-70, 2020.

Marmy, A., Rajczak, J., Delaloye, R., Hilbich, C., Hoelzle, M., Kotlarski, S., Lambiel, C., Noetzli, J., Phillips, M., and Salzmann, N.: Semi-automated calibration method for modelling of mountain permafrost evolution in Switzerland, The Cryosphere, 10, 2693-2719, 2016.

McGuire, A. D., Macdonald, R. W., Schuur, E. A. G., Harden, J. W., Kuhry, P., Hayes, D. J., Christensen, T. R., and Heimann, M.: The carbon budget of the northern cryosphere region, Current Opinion in Environmental Sustainability, 2, 231-236, 10.1016/j.cosust.2010.05.003, 2010. 
Mewes, B., Hilbich, C., Delaloye, R., and Hauck, C.: Resolution capacity of geophysical monitoring regarding permafrost degradation induced by hydrological processes, The Cryosphere, 11, 2957-2974, 2017.

Mollaret, C., Hilbich, C., Pellet, C., Flores-Orozco, A., Delaloye, R., and Hauck, C.: Mountain permafrost degradation documented through a network of permanent electrical resistivity tomography sites, The Cryosphere, 13, 2557-2578, 10.5194/tc-13-2557-2019, 2019.

Mollaret, C., Wagner, F. M., Hilbich, C., Scapozza, C., and Hauck, C.: Petrophysical joint inversion applied to alpine permafrost field sites to image subsurface ice, water, air and rock contents, Frontiers in Earth Science, 8, 85, 2020.

Murton, J. B., Kuras, O., Krautblatter, M., Cane, T., Tschofen, D., Uhlemann, S., Schober, S., and Watson, P.: Monitoring rock freezing and thawing by novel geoelectrical and acoustic techniques, Journal of Geophysical Research: Earth Surface, 121, 2309-2332, 2016.

Myhra, K. S.: Modelling Permafrost Conditions in Steep Mountain Environments, Faculty of Mathematics and Natural Sciences, University of Oslo, Doktorgradsavhandling, 159, 2016.

Myhra, K. S., Westermann, S., and Etzelmüller, B.: Modelled Distribution and Temporal Evolution of Permafrost in Steep Rock Walls Along a Latitudinal Transect in Norway by CryoGrid 2D, Permafrost and Periglacial Processes, 28, 172-182, 10.1002/ppp.1884, 2017.

Myhra, K. S., Westermann, S., and Etzelmüller, B.: Modelling conductive heat flow between steep rock walls and talus slopes-thermal processes and geomorphological implications, Frontiers in Earth Science, 7, 192, 2019.

Obu, J., Westermann, S., Bartsch, A., Berdnikov, N., Christiansen, H. H., Dashtseren, A., Delaloye, R., Elberling, B., Etzelmüller, B., and Kholodov, A.: Northern Hemisphere permafrost map based on TTOP modelling for 2000-2016 at $1 \mathrm{~km} 2$ scale, Earth-Science Reviews, 2019.

Pellet, C., Hilbich, C., Marmy, A., and Hauck, C., 2016, Soil moisture data for the validation of permafrost models using direct and indirect measurement approaches at three alpine sites: Frontiers in Earth Science, v. 3, p. 91.

Phillips, M., Wolter, A., Lüthi, R., Amann, F., Kenner, R., and Bühler, Y.: Rock slope failure in a recently deglaciated permafrost rock wall at Piz Kesch (Eastern Swiss Alps), February 2014, Earth Surface Processes and Landforms, 42, 426-438, 2017.

Ravanel, L., Allignol, F., Deline, P., Gruber, S., and Ravello, M.: Rock falls in the Mont Blanc Massif in 2007 and 2008, Landslides, 7, 493-501, DOI 10.1007/s10346-010-0206-z, 2010.

1295 Ravanel, L., Magnin, F., and Deline, P.: Impacts of the 2003 and 2015 summer heatwaves on permafrost-affected rock-walls in the Mont Blanc massif, Sci Total Environ, 609, 132-143, 2017.

Riseborough, D., Shiklomanov, N., Etzelmuller, B., Gruber, S., and Marchenko, S.: Recent advances in permafrost modelling, Permafrost and Periglacial Processes, 19, 137-156, Doi 10.1002/Ppp.615, 2008.

Rouyet, L., Kristensen, L., Derron, M.-H., Michoud, C., Blikra, L. H., Jaboyedoff, M., and Lauknes, T. R.: Evidence of rock slope breathing using ground-based InSAR, Geomorphology, 289, 152-169, 2017.

Saintot, A., Oppikofer, T., Derron, M.-H., and Henderson, I.: Large gravitational rock slope deformation in Romsdalen valley (Western Norway), Revista de la Asociación Geológica Argentina, 69, 354-371, 2012. 
Saloranta, T. M.: Simulating snow maps for Norway: description and statistical evaluation of the seNorge snow model, The Cryosphere, 6, 1323-1337, 10.5194/tc-6-1323-2012, 2012.

Schuur, E. A., McGuire, A. D., Schädel, C., Grosse, G., Harden, J., Hayes, D. J., Hugelius, G., Koven, C. D., Kuhry, P., and Lawrence, D. M.: Climate change and the permafrost carbon feedback, Nature, 520, 171, 2015.

Sen, P., Scala, C., and Cohen, M., 1981, A self-similar model for sedimentary rocks with application to the dielectric constant of fused glass beads: Geophysics, v. 46, no. 5, p. 781-795.

Slagstad, T., Balling, N., Elvebakk, H., Midttømme, K., Olesen, O., Olsen, L., and Pascal, C.: Heat-flow measurements in Late Palaeoproterozoic to Permian geological provinces in south and central Norway and a new heat-flow map of Fennoscandia and the Norwegian-Greenland Sea, Tectonophysics, 473, 341-361, 10.1016/j.tecto.2009.03.007, 2009.

Svennevig, K., Dahl-Jensen, T., Keiding, M., Merryman Boncori, J. P., Larsen, T. B., Salehi, S., Munck Solgaard, A., and Voss, P. H.: Evolution of events before and after the 17 June 2017 rock avalanche at Karrat Fjord, West Greenland - a multidisciplinary approach to detecting and locating unstable rock slopes in a remote Arctic area, Earth Surf. Dynam., 8, 1021-1038, 10.5194/esurf-8-1021-2020, 2020.

Timur, A., 1968, Velocity of compressional waves in porous media at permafrost temperatures: Geophysics, v. 33, no. 4 , p. 584-595.

Vick, L. M., Böhme, M., Rouyet, L., Bergh, S. G., Corner, G. D., and Lauknes, T. R.: Structurally controlled rock slope deformation in northern Norway, Landslides, 17, 1745-1776, 10.1007/s10346-020-01421-7, 2020.

Voigtländer, A., Leith, K., and Krautblatter, M.: Subcritical crack growth and progressive failure in Carrara marble under wet and dry conditions, Journal of Geophysical Research: Solid Earth, 123, 3780-3798, 2018.

Weber, S., Beutel, J., Faillettaz, J., Hasler, A., Krautblatter, M., and Vieli, A.: Quantifying irreversible movement in steep, fractured bedrock permafrost on Matterhorn (CH), The Cryosphere, 11, 567-583, 2017.

Westermann, S., Schuler, T. V., Gisnas, K., and Etzelmuller, B.: Transient thermal modeling of permafrost conditions in Southern Norway, Cryosphere, 7, 719-739, DOI 10.5194/tc-7-719-2013, 2013.

Wirz, V., Beutel, J., Gruber, S., Gubler, S., and Purves, R. S.: Estimating velocity from noisy GPS data for investigating the temporal variability of slope movements, Nat Hazard Earth Sys, 14, 2503-2520, 2014. 